\title{
The search for novel analgesics: targets and mechanisms
}

\section{Tony L. Yaksh*, Sarah A. Woller, Roshni Ramachandran, and Linda S. Sorkin}

Address: University of California, San Diego, Department of Anesthesiology 0818, 9500 Gilman, Dr. (CTF C-312), La Jolla, CA 92093, USA

* Corresponding author: Tony L. Yaksh (tyaksh@ucsd.edu)

Fl000Prime Reports 2015, 7:56 (doi:10.12703/P7-56)

All Fl000Prime Reports articles are distributed under the terms of the Creative Commons Attribution-Non Commercial License (http://creativecommons.org/licenses/by-nc/3.0/legalcode), which permits non-commercial use, distribution, and reproduction in any medium, provided the original work is properly cited.

The electronic version of this article is the complete one and can be found at: http://f $1000 . c o m / p r i m e /$ reports $/ \mathrm{m} / 7 / 56$

\begin{abstract}
The management of the pain state is of great therapeutic relevance to virtually every medical specialty. Failure to manage its expression has deleterious consequence to the well-being of the organism. An understanding of the complex biology of the mechanisms underlying the processing of nociceptive information provides an important pathway towards development of novel and robust therapeutics. Importantly, preclinical models have been of considerable use in determining the linkage between mechanism and the associated behaviorally defined pain state. This review seeks to provide an overview of current thinking targeting pain biology, the use of preclinical models and the development of novel pain therapeutics. Issues pertinent to the strengths and weaknesses of current development strategies for analgesics are considered.
\end{abstract}

\section{Introduction}

Failure to manage pain has important deleterious biological consequences including, but not limited to, cardiovascular pathology (hypertension, myocardial ischemia), suppression of gastrointestinal motility, suppression of spontaneous activity leading to joint and muscle deterioration, and the physiological (loss of appetite, failure to thrive) and psychological consequences of stress generated by the aversive state [1]. The negative consequences of pain are readily reflected in quality of life measures and economic indices [2-4].

Currently, there are several families of agents that have recognized clinical utility as pain therapeutics. They have varying degrees of efficacy for the different pain states and attendant adverse event profiles that often limit their utility. Management of inflammatory states typically involve nonsteroidal anti-inflammatory drugs (NSAIDs), for example, inhibitors of cyclooxygenases (COX-1 and/or COX-2) [5,6] and opiates [7]. For the states associated with nerve injury, therapies include antidepressants that block monoamine uptake (amitriptyline, duloxetine, venlafaxine) [8-10], anticonvulsants acting through a block of sodium channels (lidocaine, carbamazepine) [11-13], alteration of calcium channel function (e.g. ziconotide, gabapentin) $[14,15]$ or through increasing extracellular levels of the inhibitory transmitter gamma aminobutyric acid (GABA) (tigabine) $[16,17]$ and, to a lesser extent, opioids [7] and topical medications (lidocaine, capsaicin for patients with cutaneous allodynia and hyperalgesia) $[18,19]$. Often, combination therapies employing agents with distinct targets and non-overlapping side effect profiles may achieve improved therapeutic benefit in treating neuropathic conditions [20]. A point of interest has been whether any of these agents might be disease-modifying by preventing the transition from an acute reversible injury state to a chronic pain state (see below) $[21,22]$.

While these agents may have demonstrated efficacy, it is frequently the case that, even with aggressive management, the patient's pain remains of such a magnitude that the patient could still be eligible to be admitted into the original study [23-25]. It is often difficult to know if the efficacy is restricted by a limited role for the mechanisms targeted, limitation of the drug target engagement, or that the side effects preclude higher doses [26-28]. Development of novel therapeutics to manage pain has thus been a focus of significant effort and investment $[26,29]$. In this brief overview, we will 
consider current thinking regarding the complex biology of pain processing and how it informs the development of drug targets for analgesic therapeutics, and then offer a commentary on the screening of drugs with analgesic therapeutic potential. It should be emphasized that the above commentary is not limited to human therapies. There is a growing appreciation that the adequate treatment of pain in companion animals also presents important therapeutic issues, and the development of effective analgesics in that clinical population is itself an important target [30].

\section{Pain phenotypes}

Pain is the constellation of behavioral and physiological sequelae that can arise from three major classes of initiating conditions: (a) acute high intensity stimuli; (b) tissue injury and inflammation; and (c) injury to a specific peripheral nerve (mononeuropathy, e.g. crush, section) [9,31], or to all peripheral sensory nerves (polyneuropathy, e.g. diabetes, chemotherapy, or an immune-mediated reaction) [32,33]. The behavioral state initiated by these several conditions are intrinsically aversive, in that the state is associated with a negative affect (e.g. vocalization, facial expression) and supports complex escape and avoidance behaviors upon the first (e.g. unconditioned) exposure. These states each have defining properties.

After an acute stimulus, the pain sensation co-varies with stimulus intensity, is limited to the body region to which the stimulus is applied, and is absent with removal of stimuli.

Following tissue injury/inflammation, there is ongoing pain, which persists after removal of the injuring stimulus and the appearance of pain behavior with modest intensity stimuli applied to the injury site (primary hyperalgesia) and to adjacent uninjured regions (secondary hyperalgesia/ allodynia).

Nerve injuries (mono- and polyneuropathies) are characterized by ongoing pain states (dysesthesia) and by an exaggerated sensitivity to light touch and cold, typically referred to the peripheral distribution of the injured nerve. Mononeuropathies include direct section or compression of a nerve trunk leading to pain referred to the distribution of the injured nerve. The polyneuropathy is typically bilateral in the distal extremities and may be generated by a variety of chemical insults (cancer chemotherapeutics, retroviral drugs), viral infections such as HIV, metabolic diseases (e.g. diabetes), and autoimmune pathologies. Importantly, while the exaggerated sensitivity to low intensity stimuli may appear similar after tissue and nerve injury, it is appreciated that the mechanical sensitivity observed after nerve injury may be mediated by the sensory afferents that normally encode light touch (e.g. Aß axons) [34].

The pain states arising from local tissue injury or inflammation typically show a time course that parallels the onset and resolution of the injury state [35], whereas nerve injury often leads to a persistent condition and may show little resolution over time. Following nerve injury, long-lasting changes in thresholds and the existence of an aversive state is noted in animal models [36-38].

There is a growing appreciation that the pain state originating from prolonged inflammation may persist even when the inflammatory state (e.g. loss of neutrophils/macrophages and pro-inflammatory cytokines) resolves. Thus, following surgeries such as herniorrhaphies, arthroscopies and thoracotomies, up to $30 \%$ of the population may show pain that lasts more than 3 months [39-41]. In the classic clinical example of persistent inflammation, rheumatoid arthritis, the pathology is characterized by joint inflammation and remodeling as well as pain. While the association of pain with inflammation is not unexpected, pain may continue to present as a problem, even in patients in remission or who show minimal inflammatory signs $[42,43]$, suggesting the development of a chronic or enduring pain state. In preclinical models of acute injury and inflammation, a transient change in thresholds is commonly observed with the loss of the pain state observed with resolution of inflammation $[44,45]$. In contrast, long-lasting inflammatory states may demonstrate a resolution of inflammation with an enduring allodynia and persistent aversive component $[46,47]$. In animal models, the early phase is characterized by sensitivity to agents such as NSAIDs and agents that block hyperalgesia (gabapentin), while the late phase is characterized by a pharmacology resembling that noted with nerve injury $[46,47]$. As will be reviewed below, while pain associated with tissue injury and inflammation may be mechanistically and pharmacologically distinguishable from the states initiated by nerve injury, over time, in the persistent/chronic pain patient, there appears to be a convergence in mechanisms underlying chronic inflammation-evoked and nerve injury-evoked pain states.

\section{Preclinical characterization of the "analgesic" actions of agents}

In the following sections, we will briefly survey the biological targets that underlie the mechanisms through which the aversive stimulus environment is encoded. It is recognized that the assertion that a particular state represents a pain experience, and that conversely the actions of an agent targeting those mechanisms are "analgesic", 
depends on the effects of these manipulations upon the behavior of the intact and unanesthetized animal. Such preclinical models have been widely employed in defining the behavioral correlates of nociceptive processing reflecting acute, post-tissue injury and post-nerve injury (neuropathic) pain states. Conversely, these models may be employed to "screen" the activity of a family of agents in development to define (a) their analgesic efficacy and (b) their relative analgesic versus behavioral side effect profile. Table 1 summarizes examples of the principal classes of models. Several issues may be considered in the implementation of these models.

\section{Model paradigm}

The preclinical experimental models outlined in Table 1 may be broadly divided into three major classes. First, those that typically utilize changes in the threshold stimulus intensity (e.g. temperature/mechanical) to initiate a response or the latency to escape (evoked behaviors). Some of these behaviors may employ a response phenotype organized at the spinal level. The simplest example would be the so-called tail flick response [48]. Technically, this is a poly-synaptic reflex movement of the tail, which is evoked by an acute high intensity thermal stimulus applied to the tail that can be observed in a spinalized animal. Other escape models may involve a supraspinal component (even a simple response such as the withdrawal of a hind paw requires complex motor coordination) [49]. A variant is the emission of higher order responses such as vocalization [50] and characteristic facial expressions in rodents [51].
Second, the measurement of ongoing behaviors that are otherwise suppressed/altered in a pain state [52,53], such as ambulation [54-57], weight bearing [58], locomotor patterns, feeding, or social interactions [59-64], rearing $[65,66]$, and burrowing $[67,68]$. Third, an allied approach has sought to define the intrinsic aversiveness of a stimulus environment by employing a "conditional place preference" (CPP) paradigm to establish that a hypothesized injury state is indeed aversive and that a proposed intervention is able to attenuate that aversive component. In this, the animal with a tissue or nerve injury is exposed to a drug in a distinct environment versus a vehicle in a different environment. The animal is then permitted to choose either environment. If the injury induces an aversive state and if the drug treatment prevents/reduces that aversive state and if the treatment is not itself capable of producing a preference in a normal animal, then it is argued that the drug in the presence of the aversive state has a positive reinforcing value and will result in the selection of the paired environment [45,69-74]. A variant on this paradigm employs environments that become intrinsically aversive in the pain state, such as extreme light avoidance in a migraine model [75].

\section{False positive versus false negative outcomes in analgesic studies}

The incorrect assertion of analgesic activity of an agent may arise for several reasons. In the case of a behavioral paradigm, where the aversive stimulus evokes an escape response, a drug treatment leading to a loss of that

Table I. Summary of preclinical models

\begin{tabular}{|c|c|c|c|}
\hline Stimulus environment & Model & Time course & Reference \\
\hline Acute & Heat/cold/mechanical withdrawal & Acute & {$[409-4 I I]$} \\
\hline Acute Afferent evoked & Intraplantar formalin & Min-hours & {$[4|2,4| 3]$} \\
\hline hyperalgesia & Intraplantar capsaicin & & \\
\hline Inflammation - Acute & Carrageenan: thermal (heat and cold )/mechanical withdrawal & Min-hours & {$[320,4 \mid 4]$} \\
\hline \multirow[t]{3}{*}{ Inflammation - Chronic } & Freunds adjuvant (systemic): allodynia & Days-weeks & {$[4 \mid 5]$} \\
\hline & $\mathrm{KBxN}$ serum transfer (joint): allodynia & Days-months & {$[46]$} \\
\hline & CAIA antibody transfer (joint): allodynia & Days-months & [47] \\
\hline \multirow[t]{2}{*}{ Osteoarthritis } & $\begin{array}{l}\text { Anterior cruciate ligament section: weight bearing, activity, } \\
\text { mechanical thresholds }\end{array}$ & Days-months & {$[76,4|6,4| 7]$} \\
\hline & $\begin{array}{l}\text { lodoacetate model: weight bearing, activity, and mechanical } \\
\text { thresholds }\end{array}$ & Days-weeks & {$[4 \mid 8]$} \\
\hline Skin Incision & Plantar incision: tactile allodynia & Hours-days & [419] \\
\hline Paw Burn & Plantar burn: thermal and mechanical allodynia & Hours-days & {$[420]$} \\
\hline Visceral & $\begin{array}{l}\text { Colonic distention/inflammation: } \\
\text { pseudoaffective response, tactile sensitivity }\end{array}$ & Days-weeks & {$[421,422]$} \\
\hline Pancreatitis & Evoked inflammation: affective behavior and hypersensitivity & Days-weeks & [423] \\
\hline Bladder (Cystitis) & Evoked inflammation: abdominal hypersensitivity & Days-weeks & [424] \\
\hline Mononeuropathy & $\begin{array}{l}\text { Nerve compression: allodynia } \\
\text { Nerve ligation: allodynia } \\
\text { Needle stick: allodynia }\end{array}$ & Days-months & {$[425-427][428][433]$} \\
\hline \multirow[t]{2}{*}{ Polyneuropathy } & Diabetic model (Streptozotocin): allodynia & Days-weeks & [429] \\
\hline & Chemotherapy: tactile allodynia & Days-months & {$[430]$} \\
\hline Spinal Injury & Compression/section: tactile allodynia & Days-months & [207] \\
\hline Bone Cancer & Femoral osteosarcoma: pressure/allodynia & Days-weeks & {$[431,432]$} \\
\hline
\end{tabular}


response may be interpreted as a change in the processing of the aversive stimulus suggesting an "analgesic" treatment effect. To minimize the likelihood of a false positive, several controls may be taken. Firstly, at a minimum, this assertion of analgesic action rests upon the absence of a block of the animal's motor capacity to make the required response. Increased thresholds or latencies may reflect changes in motor strength, motor coordination, and competing arousal states (sedation or hyperactivity/ stereotypic behaviors), leading to competing behaviors. The presence of ongoing spontaneous activity, normal ambulatory patterns, and simple reflexes may be necessary to corroborate the absence of obtunding behaviors or incapacity [76]. Secondly, the use of these models provides the greatest information when performed in the context of a range of doses, concurrently with a range of doses of standard, well-characterized agents, for example, NSAIDs (such as Ibuprofen or ketorolac), anti-convulsants (such as gabapentin), and/or opiates (such as morphine). Concurrent comparison of the dose response curves for side effect profile (e.g. changes in ambulation) and the antinociceptive action allows calculation of therapeutic ratios to permit comparison of the predicted relative safety of different agents or their combinations (see, for example, [77-79]). The use of pharmacologic standards permits comparison between research groups. Thirdly, co-varying results (namely equi-effective dosing and time course) on multiple behavioral paradigms in tests with common underlying mechanisms can also be used. Given comparable hypothesized mechanisms in different models we would not anticipate major differences in potency and time course for a given agent. Such differences should be considered as unanticipated. Fourthly, covariance between pharmacokinetic and pharmacodynamics as regards behavioral effects versus time course and concentrations in plasma and brain provides an indication that the drug as formulated and delivered has a predictable target engagement (see, for example, $[80,81])$.

\section{Model selection}

Model selection in Table 1 would likely be based on one of several factors. Firstly, an assumed target mechanism (an inflammatory model such as carrageenan or $\mathrm{KBxN}$ for an anti-inflammatory agent or models of central facilitation, such as intraplantar formalin or capsaicin). Secondly, an apparent comparability of the target model with the intended clinical target (e.g. face validity: an incision model for postoperative pain or a nerve injury model for a mononeuropathy). Thirdly, the specfic clinical pathology (e.g. chemotherapy-induced neuropathy). Fourthly, the specific model choice could depend upon whether the aim was to characterize the role of a novel mechanism in a specific pain state (such as a chemotherapy neuropathy) or whether the drug target is known, and a simple "screening" model is needed to characterize the relative activity of a family of agents. Here, opiates might be examined using acute thermal escape $[82,83]$ or studies with glutamate receptor antagonists might employ the formalin flinching model $[84,85]$. Neither of those models have face validity for a clinical condition, but both reflect endpoints mediated by specific elements regulated by the respective drug targets. Labor-intensive models, such as the CPP, would be considered more appropriate to comfirm the analgesic properties of a specific target or drug effect, as opposed to the need to screen large numbers of agents.

\section{Species}

The majority of such work has involved rodents. Several points should be made. There are strain differences reported amongst mice and rats in various pain models and these must be considered when considering reported results [86]. With regard to the use of non-rodent species, experimental primate models of threshold, tissue and nerve injuries have been described [87-89], but there is no consensus that such models reveal distinctive mechanisms or are associated with increased predictive reliability. There has been an increase in interest in using other models such as companion animals (e.g. dogs and cats) in the context of clinical trials with validated behavioral inventories in animals with an ongoing clinical pathology (e.g. osteosarcoma and osteoarthritis) [90-92].

\section{Sex}

The majority of studies considering mechanisms and pharmacology of nociceptive processing have involved males. It has become apparent that, where examined, as with the role of cyclooxygenases [93], ASICs [94], toll-like receptors [95,96], and analgesics such as opiates [97], there can be significant differences between the responses of males and females.

\section{Ethical considerations}

While the importance of preclinical evaluations in pain research is apparent [86], an important caveat in the use of the unanesthetized animal to study persistent, inescapable pain states is the need to minimize unnecessary stress and utilize sufficiently powered paradigms to minimize animal use $[98,99]$. Importantly, the models listed in Table 1 have been subject to approval in the US by the relevant institutional animal care and use committees.

\section{Mechanisms of behaviorally defined pain states}

The protocol for defining systems relevant to pain processing involves demonstrating convergence between the underlying physiology of those systems that are activated by stimuli (which evoke the constellation of events defining a pain state) and the pharmacology that modifies the observed behaviorally defined pain state. 
Acute high intensity thermal or mechanical stimuli

Acute high intensity thermal or mechanical stimuli result from activation of populations of lightly myelinated (AӘ) and slowly-conducting, unmyelinated (C) fibers. As summarized in Figure 1, the response properties of these afferents are defined by thermal or mechanical transduction channels such as the TRP family of channels (TRPA1/ TRPV1) or mechanically sensitive large cation channels
[100], which are expressed in dorsal root ganglion (DRG) cells and small afferent terminals. This depolarization of the $\mathrm{C}$ nociceptor leads to conducted potentials mediated by several types of voltage-gated sodium channels, some of which are selective for small afferents (e.g. NaV 1.7, 1.8 and 1.9) [101,102]. This afferent traffic invades the central terminal, opens voltage-gated calcium channels of the $\mathrm{N}$ type (CaV2.2), which serve to mobilize populations of

Figure I. Summary of peripheral targets in nociceptive processing

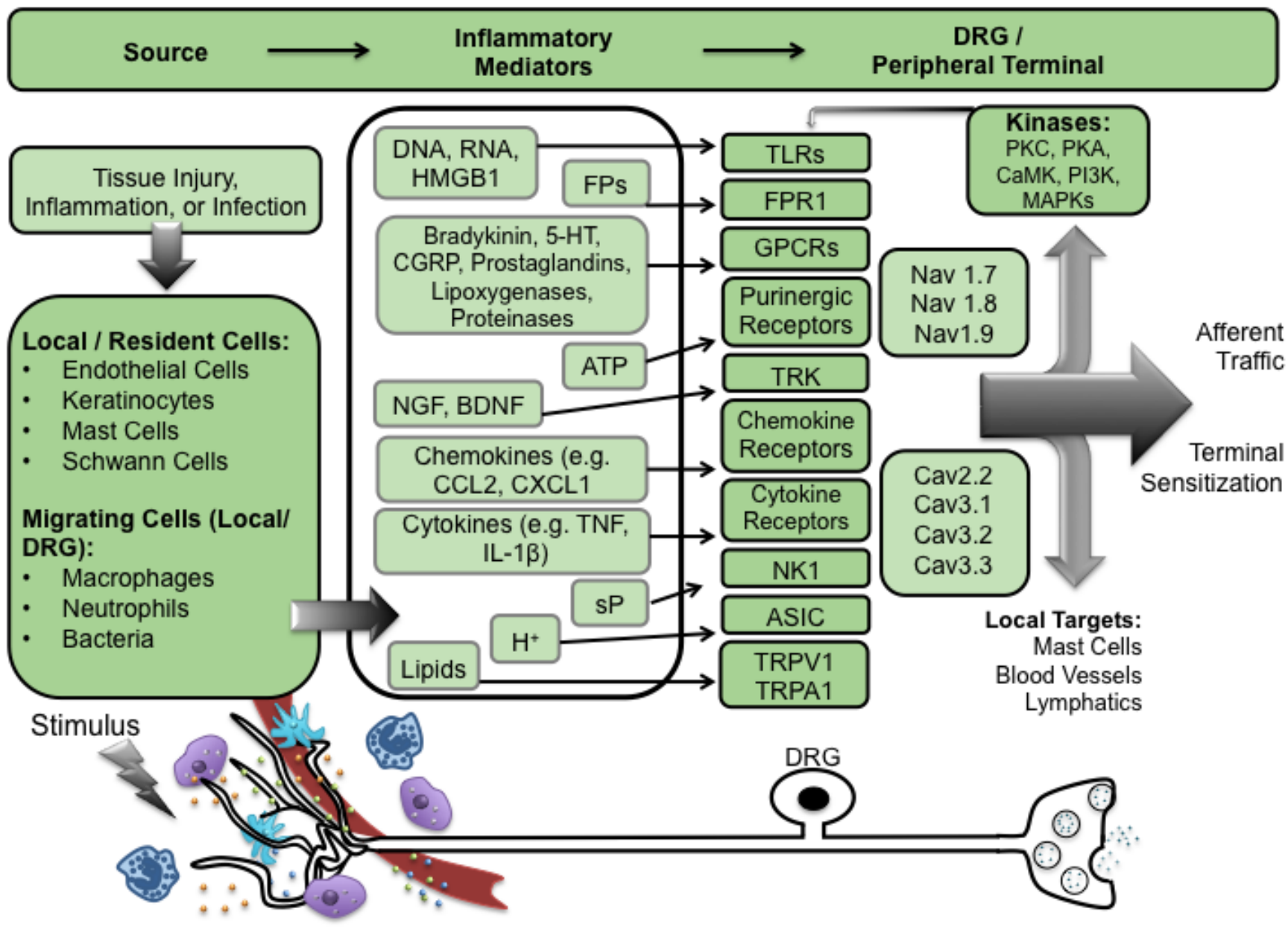

Stimuli, such as tissue injury, inflammation, or infection, lead to the release of pro-inflammatory mediators from local/resident cells (mast cells, Schwann cells), migrating cells (macrophages, neutrophils), damaged cells, and blood vessels, at the peripheral terminal. These mediators act on receptors expressed on dorsal root ganglion cells and, when activated, evoke excitation and activation of intracellular kinases. This results in the phosphorylation of receptors inducing activation at lower thresholds, increased afferent traffic, and terminal sensitization.

DRG, dorsal root ganglion; DNA, deoxyribonucleic acid; RNA, ribonucleic acid; FP, formyl peptide; 5-HT, 5-hydroxytryptamine (serotonin); CGRP, calcitonin gene related peptide; ATP, adenosine triphosphate; NGF, nerve growth factor; BDNF, brain-derived neurotrophic factor; $C C L$, chemokine (C-C motif) ligand; CX3CLI, chemokine (C-X3-C motif) ligand; TNF, tumor necrosis factor; IL, interleukin; sP, substance P; $\mathrm{H}+$, hydrogen ions; TRK, tyrosine receptor kinase; NK-I, neurokinin I; ASIC, acid-sensing ion channel; TRPVI, transient receptor potential cation channel subfamily V, member I; TRPAI, transient receptor potential cation channel, subfamily A, member I; $\mathrm{Na}_{v}$ I.7, voltage-gated sodium channel type I.7; Cav2.2, voltage gated calcium channel type 2.2; PKC, protein kinase C; PKA, protein kinase A; CaMK, calcium/calmodulin-dependent protein kinase; PI3K, phosphatidylinositol-4,5-bisphosphate 3-kinase; MAPK, mitogen-activated protein kinase; GPCR, G protein-coupled receptor; TLR, Toll-like receptor. 
synaptic proteins (soluble N-ethylmaleimide-sensitive factor activating protein receptor [SNAREs]) [103]. This results in deployment of synaptic vesicles that contain and release a variety of excitatory (glutamatergic and peptidergic) transmitters at the first order synapse; these transmitters act through eponymous ionotropic (AMPA) and metabotropic (metabotropic glutamate receptor [mGluR] 1 and 5; NK1) receptors to acutely depolarize the second order membrane [104].

The first order linkages of the primary afferents are formed with two functionally defined populations of second order neurons: those that receive largely $\mathrm{A} \partial / \mathrm{C}$ fiber input (and are hence nociceptive specific neurons) and those that receive convergent input from both low threshold $(A ß)$ and the high threshold sensory axons (referred to as wide dynamic range [WDR] neurons). In the nociceptive specific neurons, the frequency of discharge rises as stimulus intensity exceeds the threshold of the nociceptive afferents, while in the WDR neurons, the frequency of discharge progressively increases as the stimulus intensity increases over the thresholds for the low threshold and then high threshold nociceptive afferents, thus encoding as a function of frequency the range of stimulus intensity from nonaversive to aversive $[105,106]$.

The postsynaptic activation resulting from large afferents projecting into the dorsal horn is subject to pre- and postsynaptic inhibitory regulation through GABAergic and glycinergic interneurons. Loss of that inhibition will typically lead to a marked enhancement of the postsynaptic activation otherwise initiated by Aß input [107], leading in vivo to a prominent tactile evoked pain behavior (e.g. allodynia) [108].

\section{Tissue/nerve injury \\ Peripheral terminallDRG}

The ongoing pain represents ongoing small afferent traffic generated at the peripheral terminal by active factors released from blood (vascular injury, plasma extravasation), damaged/disrupted tissue, local-resident cells (keratinocytes, mast cells, endothelial cells, Schwann cells), and migrating inflammatory cells (macrophages, neutrophils) [109,110].

These factors include products derived from injured cells (RNA/DNA; H+ HMGB1) [111], or DNA released from inflammatory cells (e.g. neutrophil extracellular traps [112], endothelial cells/clotting cascade and blood (bradykinin, serotonin), a variety of local inflammatory cells yielding lipid mediators formed by cyclooxygenase (prostaglandins) and lipoxygenases (hepoxilins, 5,6epoxyeicosatrienoic acid [EET] [113-115]), proteinases (trypsin), ATP, growth factors (NGF/ brain-derived neurotrophic factor [BDNF]) [115], pro-inflammatory cytokines (tumor necrosis factor [TNF], interleukin [IL]-1 $\beta$, IL-6) [116,117], chemokines (CCL2, CXCL1 and CXCL5) [118$120]$, and Gram negative and positive bacterial products acting through toll-like receptor 4 (TLR4) and formyl peptide receptor $1[121,122]$. In addition, the local milieu is altered by products released from sympathetic (epinephrine) and primary afferent terminals (substance $\mathrm{P}$ [sP], calcitonin gene related peptide [CGRP]) [123-126].

In each case, these products act upon eponymous receptors that are expressed on peptidergic ( $\mathrm{C}$ fiber) DRG cells and, when activated, evoke excitation and activation of intracellular signaling through increased intracellular calcium ions $\left(\mathrm{Ca}^{2+}\right)$ and activation of different cascades, including that signaling through IP3, which leads to activation of a variety of terminal kinases including cyclic adenosine monophosphate (cAMP)dependent protein kinase (PKA), protein kinase C (PKC), calcium/calmodulin-dependent protein kinase (CaMK) [127], phosphoinositide 3-kinase (PI3K) [128], and mitogen-activated protein kinases (MAPKs), including extracellular signal-regulated kinase (ERK), p38 MAPK and c-Jun N-terminal kinase (JNK). These kinases phosphorylate a variety of terminal membrane channels and protein, leading to their activation at lower thresholds and with increased functionality. The net effect of these events is to initiate and sustain ongoing small afferent traffic and produce a sensitization of the terminals of small afferents, such that they display an enhanced discharge for a given stimulus intensity.

After local injury to the nerve, there is a dying back of the injured axon and reactive changes in the DRG neuron (including an increase in protein expression and the expression of various transcription factors, such as activation transcription factor 3: ATF3) and sprouting of the peripheral afferent terminal. Of interest, after persistent peripheral inflammation, peripheral terminals also show evidence of extensive sprouting and changes in the DRG, resembling those observed after nerve injury $[46,129]$. Physiologically, the injured afferent axon shows prominent ongoing activity that is believed to provide a source for the ongoing pain that often characterizes the nerve and tissue injury states $[130,131]$. The ectopic afferent activity in the injured axon has been shown to arise from the neuroma and from the dorsal root ganglion cell body [132]. The origin of this ongoing activity reflects changes in channel expression where local nerve injury and persistent inflammation can lead to the following: (a) an upregulation of sodium channels in the C-fiber afferent axon [133-135] and a downregulation of potassium channels 
[136]; (b) sympathetic ingrowth [137]; (c) cytokines and chemokines released from migration of inflammatory cells [138-140]; (d) activation of non-neuronal (satellite) cells [141]; and (e) cross-talk between ganglion neurons [142]. These effects jointly enhance excitability of the DRG membrane, leading to ectopic activity that projects into the dorsal horn. Further, as noted above, nerve injury pain states are often characterized by an exaggerated response to light touch (tactile allodynia), which is mediated, in part, by activity in large, low threshold mechanoreceptive afferents [31]. The ability of the large $A ß$ axons to drive a pain state may reflect an exaggerated activation of the WDR neurons with which they make synaptic contact, secondary to loss of intrinsic inhibition otherwise regulating large afferent input (see below).

\section{Central (spinal) sensitization}

Ongoing small afferent input leads to increased transmitter release at the first order synapse, and a robust increase in the frequency of the response evoked by large and small afferent input in dorsal horn projection neurons. The increased activity secondary to $\mathrm{C}$ fiber input leads to increased neuronal excitability, such that subsequent afferent input will evoke a greater response in these second order projection neurons, a phenomenon characterized by the classic description of the enhanced response initiated by repetitive small afferent input ("wind-up") [143]. Convergence between the pharmacology of spinal facilitation and hyperpathic states emphasizes that this enhancement of spinal afferent processing contributes mechanistically to the enhanced pain states observed after tissue and nerve injury. Components of the biology of the facilitated state are summarized in Figure 2.

\section{Enhanced excitability of the second order neuron}

Enhanced excitability of the second order neuron results from engagement of the N-methyl-D-aspartate (NMDA) receptor (a calcium ionophore) secondary to removal of a magnesium channel block [144], increased trafficking of AMPA (2-amino-3-(5-methyl-3-oxo- 1,2-oxazol-4-yl) propanoic acid) receptor subunits, leading to an increase in the expression of calcium-permeable AMPA sites [145-147] and activation of mGluRs. For glutamate, activation of group I ( $\mathrm{mGluR}_{1}$ and $\left.\mathrm{mGluR}_{5}\right)$, present on neurons and glia [148], leads to stimulation of phospholipase C, increased intracellular $\mathrm{Ca}^{2+}$ levels, activation of adenylate cyclase and induction of the ERKs/MAPKs [149]. Agents blocking these ionotropic [150-154] and group 1 metabotropic receptors (mGluR1 and mGluR5) [155,156] have potent effects upon the associated hyperalgesic states.

Increased intracellular calcium and activation of CAMP and IP3-DAG Increased intracellular calcium and activation of cAMP and IP3-DAG pathways by the metabotropic receptors lead to increases in the activity of dorsal horn kinases, including CaMK [127], PI3K [128], PKA, PKC, and MAPKs serving to phosphorylate local membrane receptors and channels enhancing their functionality, such as the NR1 and NR2A or NR2B subunits of the NMDA receptor [157-159].

\section{Other calcium-dependent pathways}

Aside from being a charge carrier, increased intracellular calcium further serves to activate a variety of intracellular enzymes that are part of multiple facilitatory cascades. Several examples can be noted. Isoforms of phospholipase A2 lead to activation of signaling by a wide variety of constitutively expressed cyclooxygenases (COX-1 and COX-2) and lipoxygenase metabolites [110,160,161]. Prostaglandin E2, which through several eponymous receptors serves by activation of protein kinases (e.g. A and C) [162] to enhance pre-synaptic voltage-gated sodium and calcium channel function (in part through enhanced channel trafficking to the membrane) [163], also acts post-synaptically by attenuating glycine receptor function, thus, reducing constitutive dorsal horn glycinemediated inhibition [164]. Nitric oxide synthases (NOSs) are constitutively expressed in neurons and glia and are activated by afferent traffic (through calcium ionophores such as NMDA and voltage gated calcium channels), leading to increased intracellular calcium $[165,166]$. Nitric oxide initiates downstream signaling through cyclic guanosine monophosphate (cGMP) and protein kinase $\mathrm{G}$ (PKG) to modulate neurotransmission through various ion channels [167] leading to the release of a variety of proalgesic factors [168]. Drugs targeted at several isoforms, notably neuronal NOSs, have been shown to possess efficacy in a variety of hyperpathic pain states $[166,169-171]$.

\section{Neuronal chloride homeostasis}

As reviewed above, current work emphasizes the importance of constitutively active glycine and GABA-A receptors (chloride ionophores) in down regulating dorsal horn afferent-evoked activation, particularly that initiated by large afferent input [172]. Following nerve injury and in the face of high levels of spinal activation, there is an increased release of BDNF from the primary afferent and from microglia [173]. BDNF, acting through tyrosine receptor kinase (TRK)B, evokes down regulation of the $\mathrm{K}^{+}-\mathrm{Cl}^{-}$co-transporter (KCC2) in dorsal horn neurons [174]. In addition, activation of WNK-SPAK kinases inhibits KCC2 via phosphorylation [175]. This decrease in KCC2 activity leads to an increase in intracellular $\mathrm{Cl}^{-}$[176-180]. Alternately, increasing intracellular $\mathrm{Cl}^{-}$can occur secondary to increasing $\mathrm{Na}+\mathrm{K}+-$ 2Cl- cotransporter-1 (NKCC1) $[176,181]$. In either case, these changes alter the result of chloride ionophore 
Figure 2. Summary of central targets in nociceptive processing

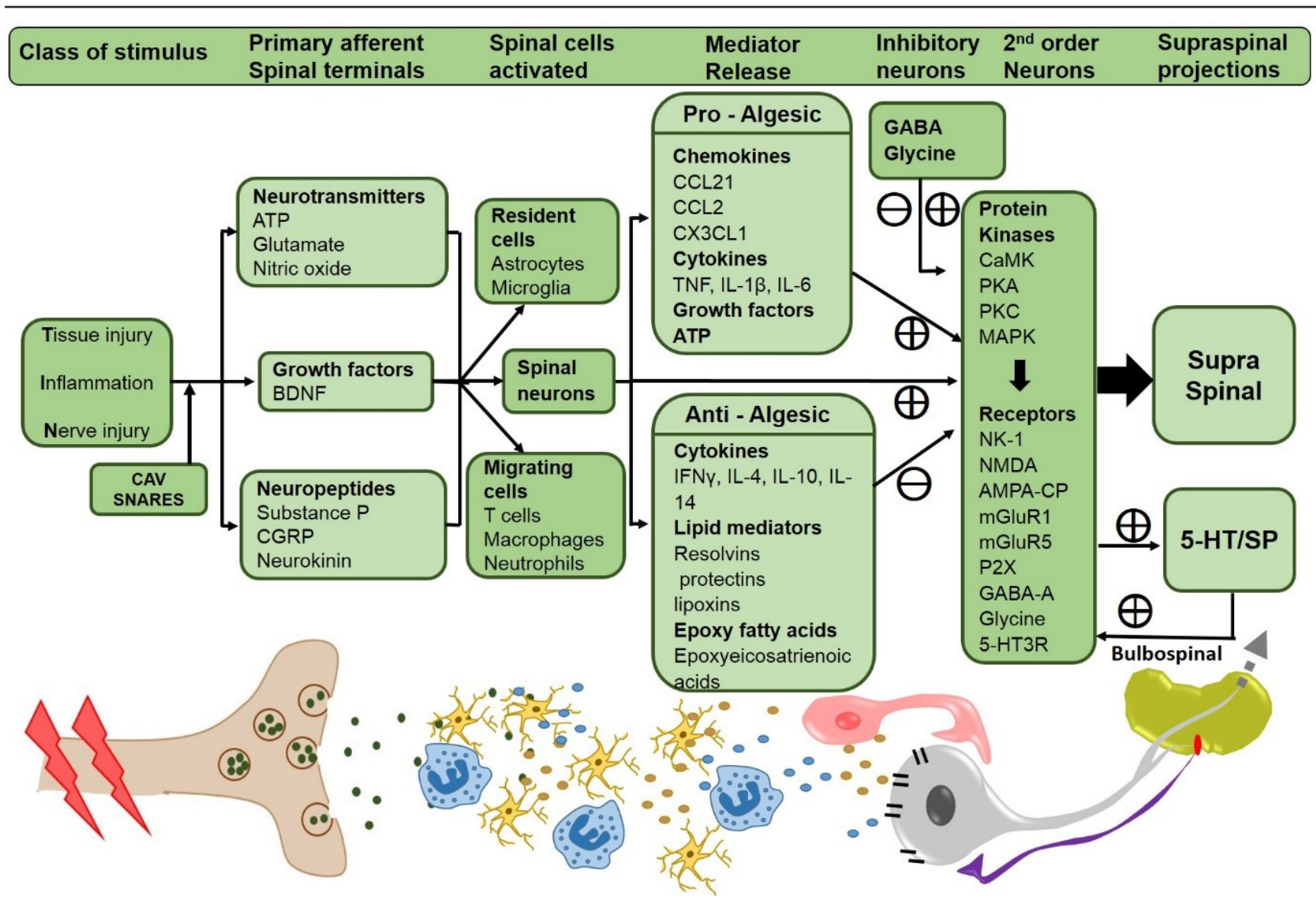

Stimuli, such as tissue injury, inflammation, or nerve injury activates the primary afferents and induces CaV and SNARE-dependent release of neurotransmitters, growth factors and neuropeptides from the spinal primary afferents. Release of these substances activates the resident glial cells and migrating cells (T cells, macrophages and neutrophils) in the spinal cord along with the second order neurons. These cells release a constellation of pro-inflammatory and anti-inflammatory molecules which further act on the second order neurons activating several protein kinases responsible for the phosphorylation of several membrane bound receptors leading to the activation of second order neurons, thus initiating and maintaining the hyperexcitable state of these neurons, and further sending the nociceptive signals to higher brain centers. The second order neurons also project onto raphe-spinal serotonergic neurons which, through the bulbospinal pathway, terminate in dorsal horn neurons and serve to facilitate the excitability of dorsal horn projection neurons.

5-HT3, 5 hydroxytryptamine 3 receptor; AMPA-CP, $\alpha$-amino-3-hydroxy-5-methyl-4-isoxazolepropionic acid receptor-calcium permeable; ATP, adenosine triphosphate; BDNF, brain-derived neurotrophic factor; CaMK, calmodulin-dependent protein kinase; CaV, voltage-gated calcium channels; $C$ CL, chemokine (C-C motif) ligand; CGRP, calcitonin gene related peptide; CX3CLI, chemokine (C-X3-C motif) ligand; GABA-A, gamma aminobutyric acid; IFN $\gamma$, interferon gamma; IL, interleukin; MAPK, mitogen-activated protein kinase; mGluR, metabotropic glutamate receptor; NK-I, neurokinin- I; NMDA, N-methyl D-aspartate; PKA, protein kinase A; PKC, protein kinase C; SNARE soluble N-ethylmaleimide-sensitive factor activating protein receptor; sP, substance P; TNF, tumor necrosis factor.

(GABA-A and glycine receptors) activation to yield membrane depolarization and hyperexcitability, rather than inhibition. Inhibition of NKCC1 with bumetanide or the recently discovered KCC2 activators lowered intracellular chloride concentrations and attenuated injury-evoked neuronal hyperactivity and hyperpathia in rodent models [181,182], emphasizing the potential utility of this approach in managing a variety of hyperpathic states influenced by this aberration of inhibitory regulation [175].
GTP Cyclohydrolase I (GCHI) and tetrahydrobiopterin (BH4)

GCH1 is present in spinal cord neurons and glia. Inflammation and nerve injury have been shown to result in its upregulation in glia and in neurons [183-185]. GCH1 is a pivotal regulator of $\mathrm{BH} 4$, an essential co-factor for nitric oxide synthase and aromatic hydroxylases that synthesize tyrosine, and several monoamines [186]. Excess $\mathrm{BH} 4$ results in a pain state and, conversely, inhibiting its synthesis reduces hyperpathic states [187]. Importantly, a $\mathrm{GCH} 1$ haplotype resulting in reduced $\mathrm{BH} 4$ synthesis has 
been associated with a pain-protective effect in experimental and clinical pain phenotypes $[188,189]$.

\section{Activation of resident non-neuronal cells}

After persistent inflammation and several forms of nerve injury, morphological changes are observed in a variety of glial cells in the peripheral nerve: Schwann cells [190], the dorsal root ganglion (satellite cells) [141], and spinal dorsal horn (microglia, astrocytes, and oligodendrocytes) [191]. Aside from morphology, persistent afferent traffic and nerve injury rapidly leads to phosphorylation of p38 MAPK isoforms and mediates the upregulation of pro-inflammatory pathways in microglia $[168,192]$. While glial activation is evident in many inflammatory and neuropathic states, it is not uniform. Thus, in some chemotherapeutic models, microglial responses are not evident [73]. This glial activation can be initiated by synaptic overflow through release from primary afferents and intrinsic neurons of a variety of molecules, including glutamate and peptides, such as sP, CGRP, angiotensin and purines (ATP). These products (delivered spinally or in cell culture) will lead to increased expression of gliotypic markers in DRG and spinal cord, and phosphorylation of intracellular transcription factors, such as ERK and p38 MAPK. Based on the anti-nociceptive suppression of glial activation of various antagonists, the action of purine in a variety of tissues and nerve injury pain states is considered to be mediated through P2X4/P2X7 $[193,194]$ and angiotensin through the AT receptor 1 [195-197], chemokines (such as fractalkine via the CX3CR1 receptor) [198], and monocyte chemoattractant protein-1 ([MCP1] through the CCR2 receptor) [199], growth factors (e.g. neuregulin-1, NRG1) through tyrosine kinase receptors erbB3 and erbB4) [200], cytokines such as TNF through TNF-r 1 and 2 [201], and a variety of products such as HMGB1 and HSP90 via the TLR4/RAGE and TLR4 receptors, respectively. Many of these products are increased in spinal cord neurons and glia with persistent inflammation and nerve injury and act upon glial TLR4 [202-204], which has been shown to be expressed on astrocytes and microglia [96]. Glial activation by the above extracellular hormones, acting through eponymous receptors on microglia and astrocytes, serves to directly increase the excitability of the primary afferent terminal and second order neuron through the increased synthesis and glial release of purines (ATP), pro-inflammatory cytokines (TNF, IL-1 $\beta$, IL-6, and interferon [IFN] $\gamma$ ) [71, 113, 205], lipid mediators (e.g. prostaglandin E2, hepoxylins, chemokines, such as CCL2) [206], and reactive-free radicals [207]. It has long been appreciated that tissue injury and inflammation increases spinal dynorphin message and expression $[208,209]$ and intrathecal dynorphin delivery initiates proalgesic factor release and hyperalgesia
$[210,211]$. Recent work has shown that spinal astrocytes produce and secrete dynorphin [212].

Conversely, injury and inflammation can reduce astrocyte expression of excitatory amino acid transporter 1 (EAAT1) and EAAT2, leading to increased extracellular concentrations of glutamate and excitation $[213,214]$. The emphasis upon glial activation has led to the effort to characterize the ability of agents reducing glial activation to attenuate nerve and post-tissue injury pain states. Agents such as cannabinoid (CB2) agonists, minocycline and propentofylline suppress glial activation and attenuate injury-evoked hyperpathia in animal models, though systematic trials have not shown promise $[215,216]$. Other approaches suppressing glial activation and injuryevoked hyperpathia include adenosine agonists $[217,218]$, inhibitors of purinergic receptors including P2X7 [219-221] and P2Y12 [222,223], inhibitors of P38 MAPK [224,225], inhibitors of NF-kß [226], and inhibitors of TLR4 signaling [227-230].

Non-resident inflammatory cells in spinal cord and DRG

Following persistent inflammation and nerve injury, the presence of macrophages and $\mathrm{T}$ cells in the DRG and spinal cord has been identified [138-140]. The origin of this transmigration arises from several mechanisms. Endothelial cells respond to chemokines such as CCchemokine ligand 2 (CCL2/MCP1) and $\mathrm{CX}_{3} \mathrm{C}$-chemokine ligand 1 ( $\mathrm{CX}_{3} \mathrm{CL} 1$ : fractalkine) with increased expression/ release of chemo-attractants such as CCL2 acting through CCR-2 to increase the presence of receptors and tethering proteins that facilitate trans-endothelial migration of monocytes and $\mathrm{T}$ cells across the blood-CNS barrier. CCL2 and CX $\mathrm{CL}_{3}$ 1 also attract monocytes and T cells to the CNS $[199,231]$, and produce an increase in neurovascular permeability secondary to the local release of transmitters from the peptidergic afferents, such as $\mathrm{sP}$ and CGRP $[232,233]$.

\section{Spinobulbospinal facilitatory pathways}

Afferent input activates lamina I neuron excitatory projections onto raphe-spinal serotonergic neurons, which, in turn, terminate in dorsal horn neurons and serve to facilitate the excitability of the dorsal horn projection neurons [234]. Lesions of this system at the level of the ascending neuron or at the descending (bulbospinal) link [235-237] abolish allodynia. These effects are thought to be mediated through a spinal 5HT3 [235] (but see [238]), 5- $\mathrm{HT}_{4}, 5-\mathrm{HT}_{6}$ and $5-\mathrm{HT}_{7}$ receptors [239].

\section{Intrinsic regulation of neuraxial processing}

Spinal nociceptive encoding of afferent input is subject to a robust up-regulation of the input-output function. 
Conversely, this excitation is subject to an extensive inhibitory control. Several examples of this regulation can be noted.

\section{GABAergic and glycinergic interneuronal systems}

These systems, through GABAA and strychnine-sensitive glycine receptors, constitutively regulate the excitation initiated by large afferent input. Thus, low-threshold primary afferent drive superficial GABAergic interneurons [240]. As reviewed above, loss of this constitutive inhibitory regulation, as occurs after peripheral inflammation and nerve injury, leads to a prominent allodynia [164,241].

\section{Glutamate initiates excitation through ionotropic and metabotropic group I (mGLul) receptors}

The metabotropic group III receptors are primarily located on presynaptic terminals, where they act through $\mathrm{G}_{\mathrm{i} / \mathrm{o}}$-coupled receptors to inhibit transmitter release through inhibition of voltage-gated calcium channels and activation of potassium channels [242]. Their activation can attenuate hyperpathic states after inflammation and nerve injury $[243,244]$.

\section{Bulbospinal regulatory systems}

Descending catecholamine-containing projections act presynaptically on dorsal horn $\alpha(2 \mathrm{~A})$-adrenoceptors on nociceptive primary afferent terminals and on second order projection neurons to regulate small afferent throughput [245]. Small afferent traffic has been shown to increase activity in these descending projections [246], and activation leads to regulation of nociceptive processing $[245,247]$.

\section{Anti-inflammatory cytokines}

As noted, inflammation and nerve injury can lead to the appearance of macrophages and lymphocytes. When activated, these cells can release significant quantities of cytokines. While widely considered in terms of their pro-inflammatory phenotype, populations of these monocytic cells can express an antiinflammatory phenotype $[248,249]$, and reduce hyperpathic states $[250,251]$. The presence of such cells is consistent with the increased spinal expression of a variety of anti-inflammatory cytokines, including IFN $\gamma$, IL-4 and IL-10 and IL-17 following nerve injury and inflammation $[159,252,253]$. Agents activating increasing expression of anti-inflammatory agents reduce allodynia following neuropathies [254]. Increasing the presence of these anti-inflammatory cytokines in the spinal space, such as after transfection with viruses [255,256] or plasmids [257], has significant antihyperalgesic actions [258].

\section{Anti-inflammatory lipid mediators}

Considerable attention is paid to proalgesic actions of the lipid mediators released by neuronal and nonneuronal cells. However, a variety of anti-algesic lipid mediators are released in the periphery and spinal cord after peripheral injury and inflammation and can serve to suppress generation of the proalgesic and proinflammatory milieu. Several examples can be noted, including those agents synthesized by a cascade of 5- and 12lipoxygenase, and cyclooxygenase 2 enzymes, the resolvins, protectins and lipoxins. Their actions are mediated by families of $G$ protein-coupled receptors (GPCRs) present on macrophages and glia [259]. Local peripheral delivery of several of these lipids reduced the expression of proinflammatory cytokines and chemokines, including TNF, IL-1 $\beta$, IL-6 and CCL2 [260]. In mice, their intrathecal delivery reduced inflammation and nerve injury-induced hyperpathia [260-263]. Another example of anti-inflammatory lipids is the metabolites of cytochrome P450 enzymes, specifically the EETs. These epoxy-fatty acids, along with epoxides of parent docosahexaenoic acid and eicosapentaenoic acid, have been shown to be anti-hyperalgesic in several pain models. The EETs are subject to rapid enzymatic degradation via the soluble epoxide hydrolase (sEH). sEH inhibition increases the concentrations of these EETs and exerts an anti-hyperalgesic action in inflammatory and neuropathic states $[264,265]$.

\section{Consideration of selected drug targets regulating nociceptive processing}

A variety of targets have been identified that can potently regulate nociceptive processing at the level of the brain and spinal cord. Several exciting areas of work are briefly noted.

\section{Opiates}

Opiates exert their potent analgesic effects through one of three identified $\mathrm{G}$ protein-coupled opioid receptors (mu, delta and kappa) [266,267]. Mechanistically, these agents exert potent effects through spinal and supraspinal interactions [268,269]. Although well-studied, opiates have been shown to have mechanisms beyond simple receptor affiliation for future target development. $\mathrm{Mu}$ opiates have been shown to have a number of splice variants. The development of novel mu opiates has been targeted at selectivity for these splice variants $[270,271]$. $\mathrm{Mu}$ opiates are normally considered to couple through $\mathrm{Gi} /$ o protein in a $ß$ arrestin-dependent fashion that serves to promote receptor internalization and desensitize G protein signaling [272]. Recent work has suggested activation can be achieved independently of $\beta$ arrestin signaling and these "G protein biased" ligands yield 
increased analgesic efficacy and persistence [273-275]. Recognizing that opiate receptors can form heterodimers with a variety of $G$ protein-coupled receptors has suggested the interesting development of a bivalent ligand, for example, interacting with opioid heterodimers, such as with a mu and delta receptor. Here, a combined mu agonist and delta antagonist ligand displays enhanced efficacy and a reduced propensity for tolerance [276,277]. Similar results have been observed with opioid and nonopioid heterodimers such as bivalent ligands for Mu - CB1 [278] and MumGluR5 [279,280]. Importantly, the enhanced properties are not mimicked when unlinked ligands focusing on the two targets are given concurrently, or if short or longer linkers are employed [281].

\section{Alpha-adrenergic agonists}

Three major alpha- 2 receptor subtypes (A-C) have been identified [282]. Dexmedetomidine and xylazine are potent alpha 2 adrenergic agonists approved as analgesics and induction (sedative) agents for human and veterinary use, respectively $[283,284]$. The specific roles of the several subtypes, namely pain processing versus the principal side effect (sedation), have been suggested [285], but are controversial.

\section{Oxytocin}

Oxytocin receptors are distributed in the superficial dorsal horn of the human spinal cord [286] and their activation has been shown to depress spinal excitability and reduce depression $[287,288]$. This spinal analgesic action may be mediated through an enhancement of GABAergic inhibition $[289,290]$.

\section{Cannabinoids}

Cannabinoids interact with two receptors (CB1/CB2), both coupling through $\mathrm{G}_{\mathrm{i} / \mathrm{o}}$ proteins [291]. Behavioral studies have shown that cannabinoids can yield prominent antinociceptive effects in a variety of animal models of acute, tissue injury-, and nerve injury-induced nociception [291]. The psychotropic effects of cannabinoids appear mediated through CB1 and not CB2 $[292,293]$. $\mathrm{CB} 1$ receptors are located on CNS neurons, notably the dorsal root ganglia [294] (while CB2 has been identified on monocytes and microglia), and their activation is believed to regulate inflammatory processes [291] in glia and to suppress glial activation [295]. Ligands interacting with the $\mathrm{G}$ protein-coupled $\mathrm{CB} 1$ and $\mathrm{CB} 2$ receptors have been shown to regulate nociceptive processing $[296,297]$. Agents increasing the presence of endogenous CB1 agonists by blocking its metabolism (through fatty acid hydrolase) have been implicated in activating cannabinoid receptor function [298]. Cannabinoid-initiated change in pain processing is based on the suppression of spinal and thalamic nociceptive neurons, but peripheral sites of action have also been identified.

\section{Novel targeting strategies for analgesics}

An exciting component of pain modulation has been the implementation of several novel approaches to modify the function of systems that process nociceptive information. A brief note on these approaches will be given below.

\section{Targeted toxins}

This approach takes advantage of toxin delivery to specific cell systems. Several examples include use of toxins coupled to agonists for G-protein-coupled receptors, which are internalized along with the receptor ligand into cells expressing the particular receptors upon activation. Such receptors include those for mu opiates and neurokinin 1 for $\mathrm{sP}$, present on cells within the spinal pain pathway. A toxin, such as saporin, coupled to these ligands is taken up by cells expressing the relevant receptor. The internalized saporin blocks ribosylation and the targeted cells die, leading to a robust analgesia in a variety of models in several species, including the rodent [299] and dog [300,301], and is currently in clinical trials (NCT02036281). The irreversibility of toxins such as saporin and resiniferatoxin will likely preclude their use in non-terminal states. Other toxins that can be delivered in this manner are the light chain of Botulinum toxins, which, when attached to $\mathrm{sP}$ (or other G protein coupled receptor ligands that undergo internalization when activated by an agonist), will lead to cleavage of SNARE protein and block transmitter release [302]. Such an approach is reversible and may find utility in long-lasting, but non-terminal pathophysiological states. TRPV1 receptors are present on the terminals of small high threshold primary afferents and, when activated by ligands such as resiniferatoxin or capsaicin, will yield desensitization of the central (after spinal delivery) or peripheral (after peripheral delivery) afferent terminals expressing the channel, leading to a robust antinociception in rodents and dogs $[303,304]$. Topicals targeted at TRPV1 receptors have been approved [305], and intrathecal resiniferatoxin is in clinical trials (NCT00804154). A further modality for targeting TRPV1 channels takes advantage of the fact that, when activated, TRPV1 forms a pore that is able to pass large charged molecules. Protonated local anesthetics (e.g. QX314), which cannot normally enter the axon, can pass through TRPV1 channels that have been opened by TRPV1 agonists such as capsaicin and produce a selective block of sodium channel function in the TRPV1 (+) afferent axons [306]. 
Gene based approaches: specific block of protein synthesis Targeting specific proteins that play a role in nociceptive processing has been accomplished with several methodologies, including intrathecally-delivered antisense and viral and nonviral transfection [307-309]. Intrathecal antisense has been employed to reduce expression of a variety of transmitters, including sP cellular matrix proteins (thrombospondin) [120] and receptors relevant to nociceptive processing, including the NK1 receptors [310], NMDA receptor subunits [311], P2X3 [118,312], TrpV1 receptors [313], and a variety of kinases, such as p38 MAPK [192,314], phospholipases [315], sodium channels - such as Nav 1.8: [316], TRKB [317], and TRPV1 [313] and transcription factors, such as transcription factor EGR1. This knock-down has been shown to yield analgesia. Transfection of small interfering RNAs has been shown to reduce $\mathrm{Nav}_{1.7}$ miRNA and protein in DRG and to reduce hyperpathia in diabetic rats [318].

\section{Gene based approaches: transfection}

Intrathecal delivery of viral vectors encoding a given protein or the use of nonviral methods, such as nanoparticles or permeabilizing systems, can enhance targeted protein expression in vivo. Several examples are noted. DRG neurons virally transduced with a vector coding for glutamic acid decarboxylase (QHGAD67) release GABA to produce an analgesic effect. Increased expression of endomorphin-2, an opioid peptide, or the preprohormone for enkephalin or $ß$ endorphin after intrathecal viral vector transfection was found to be analgesic [319-321]. Increased spinal expression of the anti-inflammatory cytokine IL-10 after intrathecal viral vector or plasmid delivery was anti-hyperalgesic [257,319,322]. Increasing expression of MAPK phosphatase-1 reduces the phosphorylation of p38 MAPKs and reduces nerve injury-evoked increases in inflammatory cytokines and chemokines and the associated hyperalgesia [323]. The $\mathrm{Ca}(2+)$ channelbinding domain 3 (CBD3) peptide was found to block the function of CaV2.2 channels and block nerve injuryinduced hyperpathia [324]. Increased expression of the potassium channel Kv1.2 reduced nerve injury-induced hyperpathia [325].

\section{Routes of analgesic delivery}

Aside from the normal routes of oral and parenteral drug delivery, several routes have particular promise in delivering analgesic therapies.

\section{Spinal delivery}

Delivery of a compound to a target site within the central nervous system may be achieved by systemic administration if the agent passes the blood-brain barrier and can be delivered in doses that achieve an analgesic effect, but do not have impairing side effects (e.g. sedation). Agents with poor CNS penetration that are believed to act at spinal targets (as many analgesics do) may be delivered intrathecally or epidurally. While not routine, where the mechanism of action results in a long duration effect (as with many of the targeted toxins and gene therapeutics discussed above) there are increasing examples of neuraxial delivery of therapeutics [326,327]. An important issue characteristic for neuraxial delivery is the formulation requirement. Typically neuraxial formulations are water-based products with a $\mathrm{pH}$ between 5 and 7 and osmolarity in the range of $300 \mathrm{mOsM}$ with minimal adjuvants (e.g. surfactants, antioxidants, or antimicrobial constituents) (see [326,328]). An additional issue to consider in developing a spinal agent is the need for specific preclinical safety evaluations employing this route of delivery (see [326]).

\section{Cutaneous delivery}

Application to the skin may be employed to achieve a circulating analgesic dosage (as with agents such as lipophilic opiates) [329], or to achieve a local effect as with topical capsaicin [330,331] or lidocaine [332] in the treatment of post-herpetic neuralgia and diabetic peripheral neuropathic pain. Topical NSAIDs provide significant pain relief in arthritis patients when applied as patches, gels, or in solutions such as dimethyl sulfoxide (DMSO), and have a lower incidence of gastrointestinal effects (see [333]). There is a growing appreciation that locally applied products, such as Botulinum toxin, may undergo uptake in the sensory afferents and fast axon transport to the DRG and central terminals [334,335] and may, in fact, undergo a transcytotic movement into adjacent neurons [336] and glia [337,338], leading to a potent homotopic analgesia [334]. These mechanisms may account for the reported efficacy of peripheral Botulinum toxin in migraine (a pain state believed to originate from intracranial meningeal afferents) [103]. The development of delivery enhancers for transdermal movement of such large molecules may yield increased therapeutic utility [339]. Transfer of drugs through the skin faces diffusion barriers (stratum corneum), methods to enhance such transfer have included microneedles to enhance skin permeability [340]. Enhanced cutaneous penetration has also been achieved through the use of nanoparticle formulations constructed from a variety of materials ranging from silica to titanium dioxide [341,342], coated microneedles [343,344], as well as electrically driven molecule movements [345-347].

\section{Transmucosal delivery}

Agents delivered orally undergo significant hepatic first pass metabolism and degradation within the gastrointestinal tract. Delivery systems can involve sprays, wafers and 
sublingual tablets. A growing focus is on transmucosal drug administration employing the nasal, rectal, and oral (buccal or sublingual) cavities. To enhance local absorption, agents may be formulated in mucoadhesive systems to enhance mucosal contact [348-350]. Buccal delivery of fentanyl has been shown to be effective in producing acute onset pain relief [351]. Inhalation and nasal absorption is another route for drug delivery. The absorption is effected through the nasal mucosa and lung [352]. This approach represents a favorable route for delivery of a variety of low and high molecular weight compounds, including peptides [353]. Of particular note, the nanoparticle formulation noted above lends itself to transmucosal absorption [354]. Of particular interest, there is evidence that delivering the agent by nasal mucosa may allow access to the central nervous system along the olfactory pathway $[355,356]$. Oxytocin has been shown to have a pain modulatory component. Delivery by the nasal route has been shown to have efficacy in migraine [357] and on pain sensitivity [358].

\section{Predictive successes/failures of preclinical models of nociception}

Preclinical work with analgesic targets has resulted in several notable successes.

\section{COX-2 inhibitors}

COX-2 inhibitors were developed to target the inducible form of the cyclooxygenases. They were found to be active in a variety of preclinical models that defined both a central and peripheral action [160] and led to trials showing clinical efficacy and subsequent approval $[359,360]$. While well tolerated in the short-term, longterm use of these agents was unexpectedly found to have deleterious cardiovascular side effects that had not been appropriately assessed in the relevant preclinical models [361].

\section{Anti-NGF therapeutics}

Anti-NGF therapeutics arose from the appreciation that NGF acting through a Trk receptor could initiate pain states, and that NGF levels rose in a variety of models of hyperpathia [362]. Development of humanized antibodies revealed important clinical efficacy in joint disease [363,364]. A caninised anti-NGF monoclonal antibody has been developed for veterinary therapeutics [365]. Osteonecrosis secondary to anti-NGF activity is an important limiting concern [366].

\section{N-type calcium channel antagonist}

Components of marine snail venom were found to block voltage-gated calcium flux and were the ligand(s) by which the N-type calcium channel was characterized [367]. Binding sites for ziconotide were found to be present in high concentrations in the spinal dorsal horn [368]. Initial preclinical work showed its efficacy in models of hyperpathic states [369,370]. Subsequent work led to the development of and clinical approval for Prialt for spinal drug delivery [371]. Recent efforts to develop a systemically active N-type calcium channel blocker failed to meet efficacy standards in Phase II clinical studies for activity in lumbosacral radiculopathy (NCT01655849), and in post-herpetic neuralgia (NCT017578) (see [372]).

\section{Gabapentinoids}

The anti-convulsant gabapentin was identified as an analgesic by off-label clinical use, prior to work showing its anti-hyperpathic activity in animal models. However, the preclinical work was essential in identifying the $\alpha 2 \partial$ auxiliary subunit of the CaV2.2 as its target $[21,373]$. Subsequent work with it and the drug pregabalin has led to its approval for use in post-herpetic neuralgia and painful diabetic neuropathy [15], as well as fibromyalgia.

\section{T-type calcium channels}

T-type calcium channels are thought to regulate the excitability of nociceptive afferents [374] and alter nociceptive processing. When used in humans, an orally active compound was found to reduce nociceptive-evoked potentials (see [372]).

\section{NaV I.7}

As noted, small afferents express NaV 1.7 channels. In the human population, gain and loss of function mutations in the $\mathrm{NaV} 1.7$ sodium channel lead, respectively, to enhanced and diminished pain states [135], providing a promising support for developing blockers for such targets. Original work with novel targeted sodium channel blockers was negative [375], but more recent work has born positive fruit in models of postherpetic neuralgia and primary erythromelalgia [376] (https://clinicaltrials.gov/ ct2/results?term=Xen+402\&Search=Search).

\section{Toxin based local anesthetics}

Toxin-based sodium channel blockers, such as neosaxitoxin and tetrodotoxin, have been shown to produce long-lasting nerve blocks (in a variety of preclinical models (see $[377,378]$ ). Human clinical trials have shown a corresponding long duration of action and efficacy [378,379] (NCT01786655, NCT01655823).

\section{Angiotensin 2 receptor antagonist}

As noted, evidence suggests that angiotensin may be present in primary afferents and can activate a variety of facilitatory cascades mediated through AT1 and AT2 receptors [380,381]. In Phase II clinical trials, an AT2 antagonist was found to be tolerated and it met its 
primary analgesic efficacy endpoint in post-herpetic neuralgia patients [382].

\section{Monoamine uptake inhibitors}

As reviewed, preclinical work has shown that a noradrenergic bulbospinal projection into the spinal cord regulates dorsal horn nociceptive processing through alpha2 adrenergic receptors with efficacy shown in modulating hyperpathia in a variety of tissue and nerve injury models [383]. In addition, forebrain projections of serotonin and norepinephrine play an important role in the regulation of affect. Such preclinical work has led to approval of agents such as duloxetine to treat chronic musculoskeletal pain (fibromyalgia), neuropathic pain associated with diabetes, including discomfort from osteoarthritis, and chronic lower back pain [384-386], and may contribute to preventing a transition from an acute to a chronic pain state [387].

\section{Clinical trial target failures}

Conversely, a number of targets have not been confirmed in clinical trials. These include a lack of apparent clinical activity in trials with neurokinin-1 receptor antagonists ([388], but see [389]), NMDA-glycine-site antagonists [390], glial inhibitors (minocycline) [391] and CB2 agonists [392].

The apparent false-positive results of the preclinical models have been discussed elsewhere (see, for example, $[26,393])$. A number of variables may alone or jointly contribute to the lack of predictive validity: (a) lack of adequate target site engagement (e.g. pharmacokinetics, lack of blood barrier penetration); (b) difference between target properties in the model and in humans (e.g. species differences in binding sites or enzyme active sites); (c) dose-limiting side effects (or off-target site actions) that were not addressed in the preclinical model; and (d) preclinical results that could not be reproduced; or (e) marginal (but statistically significant) evidence of efficacy in the preclinical model. In the case of demonstrated efficacy, robust assessments must present results based on appropriate and achievable drug target levels in models where active standards can be shown to have robust actions. In the last case, there is increasing use of multiple laboratories to confirm in-house results along with the use of an adequate blinding protocol (see a provocative discussion of these issues in [394]). Finally, absence of an adequate therapeutic effect in the human may equally reflect upon the complexity of the human state and that, for some pain phenotypes, a particular target may engage only a component of that phenotype. It is important to note that clinical pain therapies often employ agents with multiple targets and combination therapies often display an improved therapeutic benefit versus higher doses of either agent alone [20,395].

\section{Selection of targets for development}

The above overview of the biology underlying nociceptive processing emphasizes the complexity and diversity of drug targets. Rational selection of a target for development in humans is aided by a number of convergent observations. Consider these points in the context of the development of specific $\mathrm{NaV}$ channels blockers. Firstly, the selection of a drug target that has an identified action in humans. $\mathrm{NaV} 1.7$ gain-of-function and loss-of-function mutations are associated with hyperpathia and analgesia in humans [132]. There is an increasing appreciation that genetic screening of pain patient populations will likely reveal not only differences between patient populations with pain phenotypes, but also confirm or reveal the role of novel targets $[396,397]$. Secondly, confirmation of a class action with an existing drug. Systemic lidocaine at concentrations that do not block sensory axon conduction will reduce neuropathic pain states in humans [398]. Thirdly, mechanistic convergence. NaV 1.7 protein shows increased expression after nerve injury in animal models and the increased expression correlates with the development of ectopic activity [399]. Fourthly, covariance of pharmacodynamic and pharmacokinetics of drug action. Parallels between pharmacokinetics and pharmacodynamics as regards behavioral effects versus time course and concentrations in plasma and brain provides an indication that the drug as formulated and delivered has a predictable target engagement (see, for example [80,81]. A similar analysis may be considered as having been useful in the development of other novel targets such as GTP cyclohydrolase 1 (GCH1) [187], and opioid receptor splice variants [400].

\section{Development of veterinary analgesics}

The above commentary has focused on the development of human pharmaceutics through preclinical models. Though not often considered, numbers obtained from the veterinary community emphasize a similar impact in companion animal populations with the treatment costs borne by owners approaching those in the human arthritic patient $[30,401,402]$. Not surprisingly, the increasing demand for efficacious veterinary analgesics other than NSAIDs and opiates has spurred a growth in interest in veterinary products, with many large pharma having veterinary divisions or spinoffs. Noted above, a caninised anti-NGF product for osteoarthritis in dogs has been developed [365]. Spinal actions of IL-10 have been shown to display efficacy in regulating hyperpathic states [403]. Increasing IL-10 release by delivery of intrathecal transfection 
methodologies is reported to have salutary effects in canine models of persistent pain and development of a canine therapeutic would be important (http://xaludthera.com/ products/). The intrathecal toxins $\mathrm{sP}$-saporin and resniferotoxin were shown to have efficacy in canine models of osteoarthritis and osteosarcoma (see [301]). Such work has enabled their development for human use for pain in advanced cancer and they are now in clinical trials (NCT02036281; NCT00804154). These studies also provide a corresponding link to furthering their development for approval in the veterinary patient. Novel delivery of formulations, such as transmucosal delivery of buprenorphine and dexmedetommidine, have been developed for the feline patients [404]. Pathways for drug development for veterinary use resemble those required for human approval and are in the tract of development that would be employed for human application (see: http://www.fda. gov/AnimalVeterinary). It is important to note that the veterinary patient suffering from osteosarcoma and osteoarthritis displays complex behavioral patterns consistent with the pain states. Considerable effort has been expended by members of the veterinary community to develop validated behavioral inventories to define the gravity of the pain state in these patients [405-407]. It has not been lost on those interested in analgesic drug development that these clinical patients with these inventories can provide an important clinical validation in the larger animal models of analgesic efficacy and sideeffect profiles [408].

\section{Closing comments}

While there are evident limitations and pitfalls in the translation of mechanisms defined in one species to another, it is clear that the insights provided by the merging of molecular and physiological studies with the role of the characterized systems in pain behavior provides a rational tool for developing analgesic targets and drugs to engage these targets. This brief review emphasizes the complexity of a system that has evolved over the millennia to encode the events that started with the task of recognizing fundamental threats to viability and, as such, is intimately embedded in every aspect of our biological system. It is thus not surprising that modifying the function of these systems will be fraught with the likelihood that to alter one component is to have far-reaching effects on many aspects of system function. It is important to note that many of the agents with defined efficacy have a prominent effect upon afferent processing at the spinal level where alterations in the message initiated by tissue and nerve injury are encoded.

\section{Abbreviations}

BDNF, brain-derived neurotrophic factor; CaMK, calmodulin-dependent protein kinase; $\mathrm{CaV}$, voltage-gated calcium channels of the $\mathrm{N}$ type; $\mathrm{CCL}$, chemokine (C-C motif) ligand; CGRP, calcitonin gene related peptide; CPP, conditional place preference; CX3CL1, chemokine (C-X3-C motif) ligand; DRG, dorsal root ganglion; EAAT, excitatory amino acid transporter; EET, epoxyeicosatrienoic acid; ERK, extracellular signal-regulated kinase; GABA, gamma aminobutyric acid; GPCR, G protein-coupled receptor; IFN $\gamma$, interferon gamma; $\mathrm{IL}$, interleukin; JNK, c-Jun N-terminal kinase; MAPK, mitogen activated protein kinase; $\mathrm{MCP}$, monocyte chemoattractant protein; mGluR, metabotropic glutamate receptor; NMDA, N-methyl D-aspartate; NOS, nitric oxide synthase; PI3K, phosphatidylinositol-4,5-bisphosphate 3-kinase; PKA, protein kinase $\mathrm{A} ; \mathrm{PKC}$, protein kinase $\mathrm{C}$; $\mathrm{PKG}$, protein kinase G; sEH, soluble epoxide hydrolase; SNAREs, soluble $\mathrm{N}$-ethylmaleimide-sensitive factor activating protein receptor; $\mathrm{sP}$, substance $\mathrm{P}$; TLR, toll-like receptor; TNF, tumor necrosis factor; TRK, tyrosine receptor kinase; WDR, wide dynamic range.

\section{Disclosures}

Tony L. Yaksh has conducted contract research with Johnson \& Johnson, Torrey Pines Pharma., Endo Pharma, Solstice Neurosciences LLC, Epigen Biosciences, Acadia Pharma., Abbott Labs, Flowonix Medical Inc, Kalyra Pharma, Sanford Burnham, Sorrento Therapeutics, Medtronic, Asana BioSciences, LLC. Tony L. Yaksh is on the Scientific Advisory Board for Adynxx. Tony L. Yaksh was a consultant for and received a fee from Mallinkrodt LLC and Jazz Pharma. He consulted for but did not receive a fee from Adynxx, Kalyra, Afferent Pharma, Protherics Medicines Development Ltd.

\section{Acknowledgments}

During the time of this review, the authors' work was funded in part by the NIH grants DA15353 (Tony L. Yaksh), NS067459 (Linda S. Sorkin) and AR064194 (Sarah A. Woller).

\section{References}

I. Dunwoody CJ, Krenzischek DA, Pasero C, Rathmell JP, Polomano RC: Assessment, physiological monitoring, and consequences of inadequately treated acute pain. J Perianesth Nurs 2008, 23(Suppl I): SI5-27.

2. Joshi GP, Ogunnaike BO: Consequences of inadequate postoperative pain relief and chronic persistent postoperative pain. Anesthesiol Clin North America 2005, 23:2 I-36.

3. Breivik H, Collett B, Ventafridda V, Cohen R, Gallacher D: Survey of chronic pain in Europe: prevalence, impact on daily life, and treatment. Eur J Pain 2006, 10:287-333.

4. Goldberg DS, McGee SJ: Pain as a global public health priority. BMC Public Health 20I I, I I:770.

5. Ong CK, Lirk P, Tan CH, Seymour RA: An evidence-based update on nonsteroidal anti-inflammatory drugs. Clin Med Res 2007, 5:19-34. 
6. Atkinson TJ, Fudin J, Jahn HL, Kubotera N, Rennick AL, Rhorer M: What's new in NSAID pharmacotherapy: oral agents to injectables. Pain Med 20I3, I4(SuppI I):SI I-7.

7. Yaksh T, Wallace MS: Opioids, analgesia, and pain management. In Goodman \& Gilman's The Pharmacological Basis of Therapeutics. Edited by Brunton L, Chabner B, Knollman B. New York: McGraw-Hill Medical; 201 I:48I-526.

8. Sindrup SH, Otto M, Finnerup NB, Jensen TS: Antidepressants in the treatment of neuropathic pain. Basic Clin Pharmacol Toxicol 2005, 96:399-409.

9. Finnerup NB, Sindrup SH, Jensen TS: The evidence for pharmacological treatment of neuropathic pain. Pain 2010, 150:573-81.

10. Mika J, Zychowska M, Makuch W, Rojewska E, Przewlocka B: Neuronal and immunological basis of action of antidepressants in chronic pain - clinical and experimental studies. Pharmacol Rep 2013, 65: $|6||-2|$.

II. Wallace MS, Dyck JB, Rossi SS, Yaksh TL: Computer-controlled lidocaine infusion for the evaluation of neuropathic pain after peripheral nerve injury. Pain 1996, 66:69-77.

12. Dworkin RH, O'Connor AB, Backonja M, Farrar JT, Finnerup NB, Jensen TS, Kalso EA, Loeser JD, Miaskowski C, Nurmikko TJ, Portenoy RK, Rice AS, Stacey BR, Treede RD, Turk DC, Wallace MS: Pharmacologic management of neuropathic pain: evidencebased recommendations. Pain 2007, I32:237-5I.

\section{FlOOOPrime}

13. Wiffen PJ, Derry S, Moore RA, Kalso EA: Carbamazepine for chronic neuropathic pain and fibromyalgia in adults. Cochrane Database Syst Rev 2014, 4:CD00545I.

14. Wiffen PJ, Derry S, Moore RA, Aldington D, Cole P, Rice AS, Lunn MP, Hamunen K, Haanpaa M, Kalso EA: Antiepileptic drugs for neuropathic pain and fibromyalgia - an overview of Cochrane reviews. Cochrane Database Syst Rev 2013, I I:CD0 0567.

15. Moore RA, Wiffen PJ, Derry S, Toelle T, Rice AS: Gabapentin for chronic neuropathic pain and fibromyalgia in adults. Cochrane Database Syst Rev 2014, 4:CD007938.

16. Dalby NO: Inhibition of gamma-aminobutyric acid uptake: anatomy, physiology and effects against epileptic seizures. Eur J Pharmacol 2003, 479:127-37.

17. Todorov $A A$, Kolchev $C B$, Todorov $A B$ : Tiagabine and gabapentin for the management of chronic pain. Clin J Pain 2005, 21 :358-61.

18. Derry S, Wiffen PJ, Moore RA, Quinlan J: Topical lidocaine for neuropathic pain in adults. Cochrane Database Syst Rev 2014, 7: CDOI0958.

19. Smith H, Brooks JR: Capsaicin-based therapies for pain control. Prog Drug Res 2014, 68:129-146.

20. Chaparro LE, Wiffen PJ, Moore RA, Gilron I: Combination pharmacotherapy for the treatment of neuropathic pain in adults. Cochrane Database Syst Rev 2012, 7:CD008943.

21. Clarke H, Bonin RP, Orser BA, Englesakis M, Wijeysundera DN, Katz J: The Prevention of Chronic Postsurgical Pain Using Gabapentin and Pregabalin: A Combined Systematic Review and Meta-Analysis. Anest Analg 2012, I I5:428-42.

22. Chaparro LE, Smith SA, Moore RA, Wiffen PJ, Gilron I: Pharmacotherapy for the prevention of chronic pain after surgery in adults. Cochrane Database Syst Rev 2013, 7:CD008307.

\section{FlOOOPrime}

23. Häuser W, Petzke F, Sommer C: Comparative efficacy and harms of duloxetine, milnacipran, and pregabalin in fibromyalgia syndrome. J Pain 2010, II :505-21.

24. Moore RA, Straube S, Wiffen PJ, Derry S, McQuay HJ: Pregabalin for acute and chronic pain in adults. Cochrane Database Syst Rev 2009, 3:CD007076.

25. Dworkin RH, O'Connor AB, Audette J, Baron R, Gourlay GK, Haanpaa ML, Kent JL, Krane EJ, Lebel AA, Levy RM, Mackey SC, Mayer J, Miaskowski C, Raja SN, Rice AS, Schmader KE, Stacey B, Stanos S, Treede RD, Turk DC, Walco GA, Wells CD:
Recommendations for the pharmacological management of neuropathic pain: an overview and literature update. Mayo Clin Proc 2010, 85(Suppl 3):S3-14.

26. Woolf $\mathrm{C}$ : Overcoming obstacles to developing new analgesics. Nat Med 2010, 16:124I-7.

\section{FlOOOPrime

RECOMMENDED

27. Carson S, Thakurta S, Low A, Smith B, Chou R: Long-Acting Opioid Analgesics: Final Update 6 Report. In Drug Class Review. Portland: Oregon Health \& Science University; 20II.

28. Selph S, Carson S, Fu R, Thakurta S, Low A, McDonagh M: Neuropathic Pain: Final Update I Report (Internet). In Drug Class Reviews. Portland: Oregon Health \& Science University; 2011 .

29. Kissin I: The development of new analgesics over the past $\mathbf{5 0}$ years: a lack of real breakthrough drugs. Anest Analg 2010, I 1 0:780-9.

30. Muir WW, Wiese AJ, Wittum TE: Prevalence and characteristics of pain in dogs and cats examined as outpatients at a veterinary teaching hospital. I Am Vet Med Assoc 2004, 224: $1459-63$.

3I. Baron R: Neuropathic pain: a clinical perspective. Handb Exp Pharmacol 2009, 194:3-30.

32. Seretny M, Currie GL, Sena ES, Ramnarine S, Grant R, MacLeod MR, Colvin L, Fallon M: Incidence, prevalence, and predictors of chemotherapy-induced peripheral neuropathy: A systematic review and meta-analysis. Pain 2014

33. Peltier A, Goutman SA, Callaghan BC: Painful diabetic neuropathy. BMJ 2014, 348:g1799.

34. Jensen TS, Finnerup NB: Allodynia and hyperalgesia in neuropathic pain: clinical manifestations and mechanisms. Lancet Neurol 2014, 13:924-35.

35. Xu Q, Yaksh TL: A brief comparison of the pathophysiology of inflammatory versus neuropathic pain. Curr Opin Anaesthesiol 20II, 24:400-7.

36. Chaplan SR, Bach FW, Pogrel JW, Chung JM, Yaksh TL: Quantitative assessment of tactile allodynia in the rat paw. I Neurosci Methods 1994, 53:55-63.

37. Seltzer Z, Dubner R, Shir Y: A novel behavioral model of neuropathic pain disorders produced in rats by partial sciatic nerve injury. Pain 1990, 43:205-18.

38. Decosterd I, Woolf CJ: Spared nerve injury: an animal model of persistent peripheral neuropathic pain. Pain 2000, 87:149-58.

39. Kehlet $\mathrm{H}$, Jensen TS, Woolf $\mathrm{CJ}$ : Persistent postsurgical pain: risk factors and prevention. Lancet 2006, 367:1618-25.

40. Katz J, Seltzer Z: Transition from acute to chronic postsurgical pain: risk factors and protective factors. Expert Rev Neurother 2009, 9:723-44.

4I. Kehlet H, Rathmell JP: Persistent Postsurgical Pain The Path Forward through Better Design of Clinical Studies. Anesthesiology 2010, II 2:5 I4-5.

42. Wolfe $\mathrm{F}$, Michaud $\mathrm{K}$ : Assessment of pain in rheumatoid arthritis: minimal clinically significant difference, predictors, and the effect of anti-tumor necrosis factor therapy. J Rheumatol 2007, 34:1674-83.

43. Taylor P, Manger B, Alvaro-Gracia J, Johnstone R, Gomez-Reino J, Eberhardt E, Wolfe F, Schwartzman S, Furfaro N, Kavanaugh A: Patient perceptions concerning pain management in the treatment of rheumatoid arthritis. J Int Med Res 2010, 38:12।3-24.

44. Ren K, Dubner R: Inflammatory Models of Pain and Hyperalgesia. ILAR J 1999, 40: I II-8.

45. Okun A, DeFelice M, Eyde N, Ren JY, Mercado R, King T, Porreca F: Transient inflammation-induced ongoing pain is driven by TRPV I sensitive afferents. Mol Pain 20II, 7.

46. Christianson CA, Corr M, Firestein GS, Mobargha A, Yaksh TL, Svensson $\mathrm{Cl}$ : Characterization of the acute and persistent pain state present in $\mathrm{K} / \mathrm{BxN}$ serum transfer arthritis. Pain 2010, | 5 |:394-403. 
47. Bas DB, Su J, Sandor K, Agalave NM, Lundberg J, Codeluppi S, Baharpoor A, Nandakumar KS, Holmdahl R, Svensson Cl: Collagen antibody-induced arthritis evokes persistent pain with spinal glial involvement and transient prostaglandin dependency. Arthritis Rheum 2012, 64:3886-96.

48. D'amour FE, Smith DL: A method for determining loss of pain sensation. J Pharmacol Exp Ther 194I, 72:74-9.

49. van Gorp S, Deumens R, Leerink M, Nguyen S, Joosten EA, Marsala M: Translation of the rat thoracic contusion model; part I-supraspinally versus spinally mediated pain-like responses and spasticity. Spinal Cord 2014, 52:524-8.

50. Spornick N, Guptill V, Koziol D, Wesley R, Finkel J, Quezado ZM: Mouse current vocalization threshold measured with a neurospecific nociception assay: the effect of sex, morphine, and isoflurane. J Neurosci Methods 20II, 20I:390-8.

5I. Sotocinal SG, Sorge RE, Zaloum A, Tuttle AH, Martin LJ, Wieskopf JS, Mapplebeck JC, Wei P, Zhan S, Zhang S et al.: The Rat Grimace Scale: a partially automated method for quantifying pain in the laboratory rat via facial expressions. Mol Pain 2011, 7:55.

52. Mogil JS, Crager SE: What should we be measuring in behavioral studies of chronic pain in animals? Pain 2004, I I2:12-5.

53. Blackburn-Munro G: Pain-like behaviours in animals - how human are they? Trends Pharmacol Sci 2004, 25:299-305.

54. Ferreira-Gomes J, Adaes S, Castro-Lopes JM: Assessment of movement-evoked pain in osteoarthritis by the knee-bend and CatWalk tests: a clinically relevant study. J Pain 2008, 9:945-54.

55. Walker SM, Westin BD, Deumens R, Grafe M, Yaksh TL: Effects of intrathecal ketamine in the neonatal rat: evaluation of apoptosis and long-term functional outcome. Anesthesiology 2010, I I3:147-59.

\section{FlOOOPrime}

\section{RECOMMENDED}

56. Jacobs BY, Kloefkorn HE, Allen KD: Gait analysis methods for rodent models of osteoarthritis. Curr Pain Headache Rep 2014, 18:456.

57. Angeby-Möller K, Berge OG, Hamers FP: Using the CatWalk method to assess weight-bearing and pain behaviour in walking rats with ankle joint monoarthritis induced by carrageenan: effects of morphine and rofecoxib. J Neurosci Methods 2008, 174:I-9.

58. Schött E, Berge OG, Angeby-Möller K, Hammarström G, Dalsgaard CJ, Brodin E: Weight bearing as an objective measure of arthritic pain in the rat. J Pharmacol Toxicol Methods 1994, 3I:79-83.

59. Flecknell PA: Refinement of animal use-assessment and alleviation of pain and distress. Lab Anim 1994, 28:222-3I.

60. Karas AZ: Postoperative analgesia in the laboratory mouse, Mus musculus. Lab Anim (NY) 2002, 31:49-52.

61. Stevenson GW, Bilsky EJ, Negus SS: Targeting pain-suppressed behaviors in preclinical assays of pain and analgesia: effects of morphine on acetic acid-suppressed feeding in C57BL/6] mice. J Pain 2006, 7:408-16.

62. Calvino B, Creponbernard MO, Lebars D: Parallel Clinical and Behavioral-Studies of Adjuvant-Induced Arthritis in the Rat Possible Relationship with Chronic Pain. Behav Brain Res 1987, 24: II-29.

63. Krug HE, Frizelle S, McGarraugh P, Mahowald ML: Pain behavior measures to quantitate joint pain and response to neurotoxin treatment in murine models of arthritis. Pain Med 2009, 10:1218-28.

64. Suhail MS, Christianson C, Koehrn F, Malkmus SA, Mitchell W, Corr M, Yaksh TL: Effects of long term polyarthritis and subsequent NSAID treatment on activity with disassociation of tactile allodynia in the mouse. Neurocomputing 20I2, 84:47-52.

65. Matson DJ, Broom DC, Carson SR, Baldassari J, Kehne J, Cortright DN: Inflammation-induced reduction of spontaneous activity by adjuvant: $A$ novel model to study the effect of analgesics in rats. J Pharmacol Exp Ther 2007, 320:194-201.
66. Mamet J, Klukinov M, Yaksh TL, Malkmus SA, Williams S, Harris S, Manning DC, Taylor BK, Donahue RR, Porreca F, Xie JY, Oyarzo J, Brennan TJ, Subieta A, Schmidt WK, Yeomans DC: Single intrathecal administration of the transcription factor decoy AYXI prevents acute and chronic pain after incisional, inflammatory, or neuropathic injury. Pain 20|4, I55:322-33.

67. Andrews N, Harper S, Issop Y, Rice ASC: Novel, nonreflex tests detect analgesic action in rodents at clinically relevant concentrations. Ann Ny Acad Sci 201 I, I245: I I-3.

68. Jirkof P, Cesarovic N, Rettich A, Nicholls F, Seifert B, Arras M: Burrowing behavior as an indicator of post-laparotomy pain in mice. Front Behav Neurosci 2010, 4.

69. Sufka KJ: Conditioned place preference paradigm: a novel approach for analgesic drug assessment against chronic pain. Pain 1994, 58:355-66.

70. King T, Vera-Portocarrero L, Gutierrez T, Vanderah TW, Dussor G, Lai J, Fields HL, Porreca F: Unmasking the tonic-aversive state in neuropathic pain. Nat Neurosci 2009, I 2:1364-6.

FlOOOPrime

RECOMMENDED

71. Park CK, Xu ZZ, Liu T, Lu N, Serhan CN, Ji RR: Resolvin D2 Is a Potent Endogenous Inhibitor for Transient Receptor Potential Subtype VI/AI, Inflammatory Pain, and Spinal Cord Synaptic Plasticity in Mice: Distinct Roles of Resolvin DI, D2, and EI. J Neurosci 201 I, 31:18433-8.

\section{FlOOOPrime} RECOMMENDED

72. Liu P, Okun A, Ren J, Guo RC, Ossipov MH, Xie J, King T, Porreca F: Ongoing pain in the MIA model of osteoarthritis. Neurosci Lett 2011, 493:72-5.

73. Park HJ, Stokes JA, Pirie E, Skahen J, Shtaerman Y, Yaksh TL Persistent Hyperalgesia in the Cisplatin-Treated Mouse as Defined by Threshold Measures, the Conditioned Place Preference Paradigm, and Changes in Dorsal Root Ganglia Activated Transcription Factor 3: The Effects of Gabapentin, Ketorolac, and Etanercept. Anest Analg 2013, I 16:224-31.

74. Woller SA, Moreno GL, Hart N, Wellman PJ, Grau JW, Hook MA: Analgesia or Addiction?: Implications for Morphine Use after Spinal Cord Injury. J Neurotraum 2012, 29(8): 1650-1662.

75. Recober A, Kaiser EA, Kuburas A, Russo AF: Induction of multiple photophobic behaviors in a transgenic mouse sensitized to CGRP. Neuropharmacology 2010, 58:156-65.

76. Piel MJ, Kroin JS, Im HJ: Assessment of knee joint pain in experimental rodent models of osteoarthritis. Methods Mol Biol 2015, | 226:|75-8I.

77. Erichsen HK, Hao JX, Xu XJ, Blackburn-Munro G: Comparative actions of the opioid analgesics morphine, methadone and codeine in rat models of peripheral and central neuropathic pain. Pain 2005, I 16:347-58.

78. Brainin-Mattos J, Smith ND, Malkmus S, Rew Y, Goodman M, Taulane J, Yaksh TL: Cancer-related bone pain is attenuated by a systemically available delta-opioid receptor agonist. Pain 2006, I22: |74-8I.

79. Westin BD, Walker SM, Deumens R, Grafe M, Yaksh TL: Validation of a Preclinical Spinal Safety Model Effects of Intrathecal Morphine in the Neonatal Rat. Anesthesiology 2010, I 13:183-99.

\section{FlOOOPrime}

RECOMMENDED

80. Krekels EH, Angesjo M, Sjogren I, Moller KA, Berge OG, Visser SA: Pharmacokinetic-pharmacodynamic modeling of the inhibitory effects of naproxen on the time-courses of inflammatory pain, fever, and the ex vivo synthesis of TXB2 and PGE2 in rats. Pharm Res 201I, 28:156I-76.

8I. Shang GW, Liu DN, Yan LH, Cui XY, Zhang KP, Qi C, Chen J: Nociceptive stimulus modality-related difference in pharmacokinetic-pharmacodynamic modeling of morphine in the rat. Pharmacol Biochem Behav 2006, 85:464-73. 
82. Yaksh TL, Malmberg AB, Ro S, Schiller P, Goodman M: Characterization of the spinal antinociceptive activity of constrained peptidomimetic opioids. J Pharmacol Exp Ther 1995, 275:63-72.

83. Fichna J, do-Rego JC, Costentin J, Chung NN, Schiller PW, Kosson P, Janecka $A$ : Opioid receptor binding and in vivo antinociceptive activity of position 3-substituted morphiceptin analogs. Biochem Biophys Res Commun 2004, 320:53I-6.

84. Chaplan SR, Malmberg AB, Yaksh TL: Efficacy of spinal NMDA receptor antagonism in formalin hyperalgesia and nerve injury evoked allodynia in the rat. J Pharmacol Exp Ther 1997, 280:829-38.

85. Davidson EM, Coggeshall RE, Carlton SM: Peripheral NMDA and non-NMDA glutamate receptors contribute to nociceptive behaviors in the rat formalin test. Neuroreport 1997, 8:94I-6.

86. Mogil JS, Davis KD, Derbyshire SW: The necessity of animal models in pain research. Pain 2010, 15I:12-27.

87. Yaksh TL, Reddy SV: Studies in the primate on the analgetic effects associated with intrathecal actions of opiates, alphaadrenergic agonists and baclofen. Anesthesiology I98I, 54:45 I-67.

88. Carlton SM, Lekan HA, Kim SH, Chung JM: Behavioral manifestations of an experimental model for peripheral neuropathy produced by spinal nerve ligation in the primate. Pain 1994, 56:155-66.

89. Gatch MB, Negus SS, Butelman ER, Mello NK: Antinociceptive effects of cocaine/opioid combinations in rhesus monkeys. J Pharmacol Exp Ther 1995, 275:1346-54.

90. Wiseman-Orr ML, Scott EM, Reid J, Nolan AM: Validation of a structured questionnaire as an instrument to measure chronic pain in dogs on the basis of effects on health-related quality of life. Am J Vet Res 2006, 67:1826-36.

91. Brown DC, Bell M, Rhodes L: Power of treatment success definitions when the Canine Brief Pain Inventory is used to evaluate carprofen treatment for the control of pain and inflammation in dogs with osteoarthritis. Am J Vet Res 2013, 74:| $467-73$.

\section{FlOOOPrime RECOMMENDED}

92. Brown DC, Boston RC, Farrar JT: Comparison of Force Plate Gait Analysis and Owner Assessment of Pain Using the Canine Brief Pain Inventory in Dogs with Osteoarthritis. J Vet Intern Med 20I3, 27:22-30.

93. Chillingworth NL, Morham SG, Donaldson LF: Sex differences in inflammation and inflammatory pain in cyclooxygenasedeficient mice. Am J Physiol Regul Integr Comp Physiol 2006, 29 I: R327-34.

94. Chanda ML, Mogil JS: Sex differences in the effects of amiloride on formalin test nociception in mice. Am J Physiol Regul Integr Comp Physiol 2006, 29 I:R335-42.

95. Sorge RE, LaCroix-Fralish ML, Tuttle AH, Sotocinal SG, Austin JS, Ritchie J, Chanda M, Graham AC, Topham L, Beggs S, Salter MW, Mogil JS: Spinal cord Toll-like receptor 4 mediates inflammatory and neuropathic hypersensitivity in male but not female mice. J Neurosci 201 I, 31:15450-4.

96. Stokes JA, Cheung J, Eddinger K, Corr M, Yaksh TL: Toll-like receptor signaling adapter proteins govern spread of neuropathic pain and recovery following nerve injury in male mice. J Neuroinflammation 2013, 10:148.

97. Dahan A, Kest B, Waxman AR, Sarton E: Sex-specific responses to opiates: animal and human studies. Anest Analg 2008, 107:83-95.

98. Zimmermann M: Ethical guidelines for investigations of experimental pain in conscious animals. Pain 1983, 16:109-10.

99. Balcombe J, Ferdowsian $\mathrm{H}$, Briese L: Prolonged pain research in mice: trends in reference to the 3Rs. J Appl Anim Welf Sci 2013, 16:77-95.

100. Delmas P, Hao J, Rodat-Despoix L: Molecular mechanisms of mechanotransduction in mammalian sensory neurons. Nat Rev Neurosci 201 I, I 2:139-53.
I0I. Hoeijmakers JG, Faber CG, Lauria G, Merkies IS, Waxman SG: Smallfibre neuropathies-advances in diagnosis, pathophysiology and management. Nat Rev Neurol 2012, 8:369-79.

102. Bagal SK, Chapman ML, Marron BE, Prime R, Storer RI, Swain NA: Recent progress in sodium channel modulators for pain. Bioorg Med Chem Lett 2014, 24:3690-9.

103. Ramachandran R, Yaksh TL: Therapeutic use of botulinum toxin in migraine: mechanisms of action. Brit J Pharmacol 2014, | $71: 4177-92$.

104. Larsson M: Ionotropic glutamate receptors in spinal nociceptive processing. Mol Neurobiol 2009, 40:260-88.

105. Willis WD, Jr.: The somatosensory system, with emphasis on structures important for pain. Brain Res Rev 2007, 55:297-3 I3.

106. Todd AJ: Neuronal circuitry for pain processing in the dorsal horn. Nat Rev Neurosci 2010, I I:823-36.

107. Baba H, Ji RR, Kohno T, Moore KA, Ataka T, Wakai A, Okamoto M, Woolf C): Removal of GABAergic inhibition facilitates polysynaptic A fiber-mediated excitatory transmission to the superficial spinal dorsal horn. Mol Cell Neurosci 2003, 24:8I8-30.

108. Yaksh TL: Behavioral and autonomic correlates of the tactile evoked allodynia produced by spinal glycine inhibition: effects of modulatory receptor systems and excitatory amino acid antagonists. Pain 1989, 37: I I -23.

109. Kim CF, Moalem-Taylor G: Detailed characterization of neuroimmune responses following neuropathic injury in mice. Brain Res 2011, I405:95-108.

II0. Ellis $A$, Bennett DL: Neuroinflammation and the generation of neuropathic pain. Br J Anaesth 20I3, I I I:26-37.

III. Scaffidi P, Misteli T, Bianchi ME: Release of chromatin protein HMGB I by necrotic cells triggers inflammation. Nature 2002, 418:191-5.

\section{FlOOOPrime}

RECOMMENDED

II2. Luo L, Zhang S, Wang Y, Rahman M, Syk I, Zhang E, Thorlacius H: Pro-inflammatory role of neutrophil extracellular traps in abdominal sepsis. Am J Physiol Lung Cell Mol Physiol 2014, 307:586-96.

113. Gregus AM, Doolen S, Dumlao DS, Buczynski MW, Takasusuki T, Fitzsimmons BL, Hua XY, Taylor BK, Dennis EA, Yaksh TL: Spinal 12-lipoxygenase-derived hepoxilin $A 3$ contributes to inflammatory hyperalgesia via activation of TRPVI and TRPAI receptors. Proc Natl Acad Sci U S A 2012, 109:6721-6.

1 14. Sisignano M, Park CK, Angioni C, Zhang DD, von Hehn C, Cobos EJ, Ghasemlou N, Xu ZZ, Kumaran V, Lu RR, Grant A, Fischer MJ, Schmidtko A, Reeh P, Ji RR, Woolf CJ, Geisslinger G, Scholich K, Brenneis C: 5,6-EET Is Released upon Neuronal Activity and Induces Mechanical Pain Hypersensitivity via TRPAI on Central Afferent Terminals. J Neurosci 2012, 32:6364-72.

115. Boyce VS, Mendell LM: Neurotrophins and spinal circuit function. Front Neural Circuits 2014, 8:59.

116. Niu X, Chen G: Clinical biomarkers and pathogenic-related cytokines in rheumatoid arthritis. J Immunol Res 2014, 2014:698192.

117. Miller RE, Miller RJ, Malfait AM: Osteoarthritis joint pain: The cytokine connection. Cytokine 2014.

I18. Barclay J, Patel S, Dorn G, Wotherspoon G, Moffatt S, Eunson L, Abdel'al S, Natt F, Hall J, Winter J, Bevan S, Wishart W, Fox A, Ganju P: Functional downregulation of P2X3 receptor subunit in rat sensory neurons reveals a significant role in chronic neuropathic and inflammatory pain. J Neurosci 2002, 22:8139-47.

119. Biber K, Boddeke E: Neuronal CC chemokines: the distinct roles of CCL2I and CCL2 in neuropathic pain. Front Cell Neurosci 2014, 8:210.

120. Li KW, Kim DS, Zaucke F, Luo ZD: Trigeminal nerve injuryinduced thrombospondin-4 up-regulation contributes to orofacial neuropathic pain states in a rat model. Eur J Pain 2014, 18:489-95. 
121. Chiu IM, Heesters BA, Ghasemlou N, Von Hehn CA, Zhao F, Tran J, Wainger B, Strominger A, Muralidharan S, Horswill AR, Bubeck Wardenburg J, Hwang SW, Carroll MC, Woolf C): Bacteria activate sensory neurons that modulate pain and inflammation. Nature 2013, 501:52-7.

\section{FlOOOPrime} RECOMMENDED

122. Nizet V, Yaksh T: Neuroscience: Bacteria get on your nerves. Nature 2013, 50 I:43-4.

123. Janig W, Levine JD, Michaelis M: Interactions of sympathetic and primary afferent neurons following nerve injury and tissue trauma. Prog Brain Res 1996, I I3:161-84.

124. Kelly S, Dunham JP, Donaldson LF: Sensory nerves have altered function contralateral to a monoarthritis and may contribute to the symmetrical spread of inflammation. Eur J Neurosci 2007, 26:935-42.

125. Li D, Ren Y, Xu X, Zou X, Fang L, Lin Q: Sensitization of primary afferent nociceptors induced by intradermal capsaicin involves the peripheral release of calcitonin gene-related Peptide driven by dorsal root reflexes. J Pain 2008, 9: I I55-68.

126. Drummond PD: Sensory-autonomic interactions in health and disease. Handb Clin Neurol 2013, I I 7:309-19.

127. Fang L, Wu J, Lin Q, Willis WD: Neuroinflammation and the generation of neuropathic pain. J Neurosci 2002, 22:4196-204.

128. Pezet S, Marchand F, D'Mello R, Grist J, Clark AK, Malcangio M, Dickenson AH, Williams RJ, McMahon SB: Phosphatidylinositol 3kinase is a key mediator of central sensitization in painful inflammatory conditions. J Neurosci 2008, 28:426I-70.

129. Jimenez-Andrade JM, Mantyh PW: Sensory and sympathetic nerve fibers undergo sprouting and neuroma formation in the painful arthritic joint of geriatric mice. Arthritis Res Ther 2012, I4:RI0I.

\section{FlOOOPrime}

\section{RECOMMENDED}

130. Pitcher GM, Henry JL: Governing role of primary afferent drive in increased excitation of spinal nociceptive neurons in a model of sciatic neuropathy. Exp Neurol 2008, 214:219-28.

I3I. Haroutounian S, Nikolajsen L, Bendtsen TF, Finnerup NB, Kristensen AD, Hasselstrom JB, Jensen TS: Primary afferent input critical for maintaining spontaneous pain in peripheral neuropathy. Pain 2014, I55:1272-9.

132. Devor M, Wall PD, Catalan N: Systemic Lidocaine Silences Ectopic Neuroma and Drg Discharge without Blocking Nerve-Conduction. Pain 1992, 48:261-8.

133. Devor $M$ : Sodium channels and mechanisms of neuropathic pain. J Pain 2006, 7(Suppl I):S3-I2.

134. Strickland IT, Martindale JC, Woodhams PL, Reeve AJ, Chessell IP, McQueen DS: Changes in the expression of NaVI.7, NaVI.8 and $\mathrm{NaVI} .9$ in a distinct population of dorsal root ganglia innervating the rat knee joint in a model of chronic inflammatory joint pain. Eur J Pain 2008, 1 2:564-72.

135. Dib-Hajj SD, Cummins TR, Black JA, Waxman SG: Sodium channels in normal and pathological pain. Annu Rev Neurosci 2010, 33:325-47.

I36. Chien LY, Cheng JK, Chu D, Cheng CF, Tsaur ML: Reduced expression of A-type potassium channels in primary sensory neurons induces mechanical hypersensitivity. J Neurosci 2007, 27:9855-65.

137. McLachlan EM, Hu P: Inflammation in dorsal root ganglia after peripheral nerve injury: effects of the sympathetic innervation. Auton Neurosci 2014, 182:108-17.

138. Chang YW, Winkelstein BA: Schwann Cell Proliferation and Macrophage Infiltration Are Evident at Day I4 after Painful Cervical Nerve Root Compression in the Rat. J Neurotraum 20I I, 28:2429-38.

139. Miller RE, Tran PB, Das R, Ghoreishi-Haack N, Ren D, Miller RJ, Malfait AM: CCR2 chemokine receptor signaling mediates pain in experimental osteoarthritis. Proc Natl Acad Sci USA 2012, 109:20602-7.

FIOOOPYIMP
RECOMMENDED

140. Schmid AB, Coppieters MW, Ruitenberg MJ, McLachlan EM: Local and remote immune-mediated inflammation after mild peripheral nerve compression in rats. J Neuropathol Exp Neurol 2013, 72:662-80.

14I. Blum E, Procacci P, Conte V, Hanani M: Systemic inflammation alters satellite glial cell function and structure. A possible contribution to pain. Neuroscience 2014, 274:209-I7.

142. Ma C, Shu Y, Zheng Z, Chen Y, Yao H, Greenquist KW, White FA, LaMotte RH: Similar electrophysiological changes in axotomized and neighboring intact dorsal root ganglion neurons. J Neurophysiol 2003, 89: I588-602.

143. Mendell LM, Wall PD: Responses of Single Dorsal Cord Cells to Peripheral Cutaneous Unmyelinated Fibres. Nature 1965, 206:97-9.

144. Paoletti P: Molecular basis of NMDA receptor functional diversity. Eur J Neurosci 20I I, 33: I35 I-65.

145. Vikman KS, Rycroft BK, Christie MJ: Switch to Ca2+-permeable AMPA and reduced NR2B NMDA receptor-mediated neurotransmission at dorsal horn nociceptive synapses during inflammatory pain in the rat. J Physiol-London 2008, 586:5I5-27.

146. Kopach O, Kao SC, Petralia RS, Belan P, Tao YX, Voitenko N: Inflammation alters trafficking of extrasynaptic AMPA receptors in tonically firing lamina II neurons of the rat spinal dorsal horn. Pain 201I, I52:912-23.

147. Studniarczyk D, Coombs I, Cull-Candy SG, Farrant M: TARP gamma-7 selectively enhances synaptic expression of calciumpermeable AMPARs. Nat Neurosci 2013, 16:1266-74.

\section{FlOOOPrime} RECOMMENDED

148. Biber K, Laurie DJ, Berthele A, Sommer B, Tolle TR, GebickeHarter PJ, van Calker D, Boddeke HW: Expression and signaling of group I metabotropic glutamate receptors in astrocytes and microglia. J Neurochem 1999, 72:167I-80.

149. Sheffler DJ, Gregory KJ, Rook JM, Conn PJ: Allosteric modulation of metabotropic glutamate receptors. Adv Pharmacol 2011, 62:37-77.

150. Petrenko AB, Yamakura T, Baba H, Shimoji K: The role of $\mathbf{N}$ methyl-D-aspartate (NMDA) receptors in pain: a review. Anest Analg 2003, 97:I 108-16.

I5I. Collins S, Sigtermans MJ, Dahan A, Zuurmond WW, Perez RS: NMDA receptor antagonists for the treatment of neuropathic pain. Pain Med 2010, I I:I726-42.

152. Sorkin L, Yaksh TL, Doom CM: Mechanical allodynia in rats is blocked by a Ca2+ permeable AMPA receptor antagonist. Neuroreport. Neuroreport 1999, 10:3523-6.

153. Jones TL, Sorkin LS: Calcium-permeable alpha-amino-3hydroxy-5-methyl-4-isoxazolepropionic acid/kainate receptors mediate development, but not maintenance, of secondary allodynia evoked by first-degree burn in the rat. JPET 2004, 10:223-9.

154. Osikowicz M, Mika J, Przewlocka B: The glutamatergic system as a target for neuropathic pain relief. Exp Physiol 20I3, 98:372-84.

155. Varty GB, Grilli M, Forlani A, Fredduzzi S, Grzelak ME, Guthrie DH, Hodgson RA, Lu SX, Nicolussi E, Pond AJ, Parker EM, Hunter JC, Higgins GA, Reggiani A, Bertorelli R: The antinociceptive and anxiolytic-like effects of the metabotropic glutamate receptor 5 (mGluR5) antagonists, MPEP and MTEP, and the mGluRI antagonist, LY456236, in rodents: a comparison of efficacy and side-effect profiles. Psychopharmacology (Berl) 2005, I 79:207-I7.

156. Owen DR: Recent advances in the medicinal chemistry of the metabotropic glutamate receptor I (mGlu(I)). ACS Chem Neurosci 2011, 2:394-401. 
157. Ji RR, Gereau RWt, Malcangio M, Strichartz GR: MAP kinase and pain. Brain Res Rev 2009, 60:I35-48.

\section{FlOOOPrime}

158. Zhang RX, Li A, Liu B, Wang L, Ren K, Zhang H, Berman BM, Lao L: IL-I ra alleviates inflammatory hyperalgesia through preventing phosphorylation of NMDA receptor NR-I subunit in rats. Pain 2008, 135:232-9.

159. Meng $X$, Zhang Y, Lao L, Saito R, Li A, Backman CM, Berman BM, Ren K, Wei PK, Zhang RX: Spinal interleukin-I7 promotes thermal hyperalgesia and NMDA NRI phosphorylation in an inflammatory pain rat model. Pain 2013, 154:294-305.

160. Svensson Cl, Yaksh TL: The spinal phospholipase-cyclooxygenaseprostanoid cascade in nociceptive processing. Annu Rev Pharmacol Toxicol 2002, 42:553-83.

161. Grace PM, Hutchinson MR, Maier SF, Watkins LR: Pathological pain and the neuroimmune interface. Nat Rev Immunol 2014, 14:2|7-31.

162. Okuse K: Pain signalling pathways: From cytokines to ion channels. Int J Biochem Cell B 2007, 39:490-6.

163. Liu C, Li Q, Su Y, Bao L: Prostaglandin E2 promotes NavI.8 trafficking via its intracellular RRR motif through the protein kinase A pathway. Traffic 2010, I I:405-I7.

164. Zeilhofer HU: Loss of glycinergic and GABAergic inhibition in chronic pain-contributions of inflammation and microglia. Int Immunopharmacol 2008, 8: 182-7.

165. Kanwar JR, Kanwar RK, Burrow H, Baratchi S: Recent Advances on the Roles of NO in Cancer and Chronic Inflammatory Disorders. Curr Med Chem 2009, 16:2373-94.

166. Ahlawat A, Rana A, Goyal N, Sharma S: Potential role of nitric oxide synthase isoforms in pathophysiology of neuropathic pain. Inflammopharmacology 2014, 22:269-78.

167. Ghasemi M, Fatemi A: Chloride extrusion enhancers as novel therapeutics for neurological diseases. Neurosci Biobehav Rev 2014, 45: 168-82.

168. Matsui T, Svensson Cl, Hirata Y, Mizobata K, Hua XY, Yaksh TL: Release of Prostaglandin E-2 and Nitric Oxide from Spinal Microglia Is Dependent on Activation of p38 MitogenActivated Protein Kinase. Anest Analg 2010, II I:554-60.

169. Malmberg AB, Yaksh TL: Spinal nitric oxide synthesis inhibition blocks NMDA-induced thermal hyperalgesia and produces antinociception in the formalin test in rats. Pain 1993, 54:291-300.

170. Tang Q, Svensson Cl, Fitzsimmons B, Webb M, Yaksh TL, Hua XY: Inhibition of spinal constitutive NOS-2 by $1400 \mathrm{~W}$ attenuates tissue injury and inflammation-induced hyperalgesia and spinal p38 activation. Eur J Neurosci 2007, 25:2964-72.

17I. Mukherjee P, Cinelli MA, Kang S, Silverman RB: Development of nitric oxide synthase inhibitors for neurodegeneration and neuropathic pain. Chem Soc Rev 20I4, 43:68I4-38.

172. Zeilhofer HU, Wildner H, Yevenes GE: Fast synaptic inhibition in spinal sensory processing and pain control. Physiol Rev 2012, 92:193-235.

173. Lever IJ, Bradbury EJ, Cunningham JR, Adelson DW, Jones MG, McMahon SB, Marvizon JCG, Malcangio M: Brain-derived neurotrophic factor is released in the dorsal horn by distinctive patterns of afferent fiber stimulation. J Neurosci 200I, 21:4469-77.

174. Coull JA, Beggs S, Boudreau D, Boivin D, Tsuda M, Inoue K, Gravel C, Salter MW, De Koninck Y: BDNF from microglia causes the shift in neuronal anion gradient underlying neuropathic pain. Nature 2005, 438:1017-21.

\section{FlOOOPrime}

\section{RECOMMENDED}

175. Kahle KT, Khanna A, Clapham DE, Woolf CJ: Therapeutic restoration of spinal inhibition via druggable enhancement of potassium-chloride cotransporter KCC2-mediated chloride extrusion in peripheral neuropathic pain. JAMA Neurol 2014, $71: 640-5$.

176. Coull JAM, Boudreau D, Bachand K, Prescott SA, Nault F, Sik A, De Koninck $P$, De Koninck $Y$ : Trans-synaptic shift in anion gradient in spinal lamina I neurons as a mechanism of neuropathic pain. Nature 2003, 424:938-42.

177. Funk K, Woitecki A, Franjic-Wurtz C, Gensch T, Mohrlen F, Frings S: Modulation of chloride homeostasis by inflammatory mediators in dorsal root ganglion neurons. Mol Pain 2008, 4:32.

178. Li YQ, Li H, Wei J, Qu L, Wu LA: Expression changes of $\mathbf{K + - C l -}$ co-transporter 2 and $\mathrm{Na}+-\mathrm{K}+-\mathrm{Cl}$ - co-transporter $\mathrm{I}$ in mouse trigeminal subnucleus caudalis following pulpal inflammation. Brain Res Bull 20I0, 8I:56I-4.

179. Zhou HY, Chen SR, Byun HS, Chen H, Li L, Han HD, Lopez-Berestein G, Sood AK, Pan HL: N-methyl-D-aspartate receptor- and calpain-mediated proteolytic cleavage of $\mathrm{K}+-\mathrm{Cl}$ - cotransporter-2 impairs spinal chloride homeostasis in neuropathic pain. J Biol Chem 20I2, 287:33853-64.

180. de Los Heros P, Alessi DR, Gourlay R, Campbell DG, Deak M, Macartney TJ, Kahle KT, Zhang J: The WNK-regulated SPAK/ OSRI kinases directly phosphorylate and inhibit the $\mathrm{K}+-\mathrm{Cl}-$ co-transporters. Biochem J 2014, 458:559-73.

18I. Chen SR, Zhu L, Chen H, Wen L, Laumet G, Pan HL: Increased Spinal Cord NKCCI Activity Contributes to Impairment of Synaptic Inhibition in Paclitaxel-induced Neuropathic Pain. J Biol Chem 2014.

182. Gagnon M, Bergeron MJ, Lavertu G, Castonguay A, Tripathy S, Bonin RP, Perez-Sanchez J, Boudreau D, Wang B, Dumas L, Valade I, Bachand $K$, Jacob-Wagner M, Tardif C, Kianicka I, Isenring P, Attardo G, Coull JA, De Koninck Y: Chloride extrusion enhancers as novel therapeutics for neurological diseases. Nature Medicine 2013, 19:1524-8.

183. Costigan M, Befort K, Karchewski L, Griffin RS, D'Urso D, Allchorne A, Sitarski J, Mannion JW, Prat RE, Woolf CJ: Replicate high-density rat genome oligonucleotide microarrays reveal hundreds of regulated genes in the dorsal root ganglion after peripheral nerve injury. BMC Neurosci 2002, 3:16.

184. D'Sa C, Hirayama K, West A, Hahn M, Zhu M, Kapatos G: Tetrahydrobiopterin biosynthesis in $\mathrm{C} 6$ glioma cells: induction of GTP cyclohydrolase I gene expression by lipopolysaccharide and cytokine treatment. Brain Res Mol Brain Res 1996, 4I: I05-10.

185. Meng C, Liang X, Li Q, Chen G, Liu H, Li K: Changes of GTP cyclohydrolase $I$ and neuronal apoptosis in rat spinal dorsal cord induced by sciatic nerve injury. Neurol Sci 20I3, 34:2 I 45-50.

186. Latremoliere A, Costigan M: GCHI, BH4 and pain. Curr Pharm Biotechnol 201 I, I 2:1728-4I.

187. Costigan M, Latremoliere A, Woolf CJ: Analgesia by inhibiting tetrahydrobiopterin synthesis. Curr Opin Pharmacol 20I2, 1 2:92-9.

188. Tegeder I, Costigan M, Griffin R, Abele A, Belfer I, Schmidt H, Ehnert C, Nejim J, Marian C, Scholz J, Wu T, Allchorne A, Diatchenko L, Binshtok AM, Goldman D, Adolph J, Sama S, Atlas SJ, Carlezon WA, Parsegian A, Lötsch J, Fillingim RB, Maixner W, Geisslinger G, Max MB, Woolf CJ: GTP cyclohydrolase and tetrahydrobiopterin regulate pain sensitivity and persistence. Nat Med 2006, 12:1269-77.

\section{FlOOOPrime
RECOMMENDED}

189. Tegeder I, Adolph J, Schmidt H, Woolf CJ, Geisslinger G, Lotsch J: Reduced hyperalgesia in homozygous carriers of a GTP cyclohydrolase I haplotype. Eur J Pain 2008, I2:1069-77.

190. Ydens E, Lornet G, Smits V, Goethals S, Timmerman V, Janssens S: The neuroinflammatory role of Schwann cells in disease. Neurobiol Dis 2013, 55:95-103.

191. Ji RR, Berta T, Nedergaard M: Glia and pain: is chronic pain a gliopathy? Pain 2013, I54:SI0-28.

192. Svensson C, Lucas KK, Hua XY, Powell HC, Dennis EA, Yaksh TL: Spinal phospholipase A2 in inflammatory hyperalgesia: role 
of the small, secretory phospholipase A2. Neuroscience 2005, 133:543-53.

193. Tsuda M, Masuda T, Tozaki-Saitoh H, Inoue K: $\mathbf{P 2 X} 4$ receptors and neuropathic pain. Front Cell Neurosci 2013, 7:191.

194. Barragan-Iglesias P, Pineda-Farias JB, Cervantes-Duran C, BravoHernandez M, Rocha-Gonzalez HI, Murbartian J, Granados-Soto V: Role of spinal P2Y6 and P2YII receptors in neuropathic pain in rats: possible involvement of glial cells. Mol Pain 2014, I0:29.

195. Nemoto W, Nakagawasai O, Yaoita F, Kanno SI, Yomogida S, Ishikawa M, Tadano T, Tan-No K: Angiotensin II produces nociceptive behavior through spinal ATI receptor-mediated p38 mitogen-activated protein kinase activation in mice. Mol Pain 2013, 9.

196. Pavel J, Tang H, Brimijoin S, Moughamian A, Nishioku T, Benicky J, Saavedra JM: Expression and transport of Angiotensin II ATI receptors in spinal cord, dorsal root ganglia and sciatic nerve of the rat. Brain Res 2008, 1246: I II-22.

197. Pavel J, Oroszova Z, Hricova L, Lukacova N: Effect of Subpressor Dose of Angiotensin II on Pain-Related Behavior in Relation with Neuronal Injury and Activation of Satellite Glial Cells in the Rat Dorsal Root Ganglia. Cell Mol Neurobiol 2013, 33:68I-8.

198. Clark AK, Malcangio M: Fractalkine/CX3CRI signaling during neuropathic pain. Front Cell Neurosci 20I4, 8:I2I.

199. White FA, Feldman P, Miller RJ: Chemokine signaling and the management of neuropathic pain. Mol Interv 2009, 9:188-95.

200. Calvo M, Zhu N, Tsantoulas C, Ma Z, Grist J, Loeb JA, Bennett DL: Neuregulin-ErbB signaling promotes microglial proliferation and chemotaxis contributing to microgliosis and pain after peripheral nerve injury. J Neurosci 2010, 30:5437-50.

20I. Cabal-Hierro L, Lazo PS: Signal transduction by tumor necrosis factor receptors. Cell Signal 20I2, 24:I297-305.

202. Hutchinson MR, Ramos KM, Loram LC, Wieseler J, Sholar PW, Kearney JJ, Lewis MT, Crysdale NY, Zhang Y, Harrison JA, Maier SF, Rice KC, Watkins LR: Evidence for a role of heat shock protein90 in toll like receptor 4 mediated pain enhancement in rats. Neuroscience 2009, 164:1821-32.

203. Feldman P, Due MR, Ripsch MS, Khanna R, White FA: The persistent release of HMGBI contributes to tactile hyperalgesia in a rodent model of neuropathic pain. J Neuroinflammation 2012, 9: 180 .

\section{FlOOOPrime}

204. Agalave NM, Larsson M, Abdelmoaty S, Su J, Baharpoor A, Lundback P, Palmblad K, Andersson U, Harris H, Svensson Cl: Spinal HMGB I induces TLR4-mediated long-lasting hypersensitivity and glial activation and regulates pain-like behavior in experimental arthritis. Pain 2014, I55:1802-13.

205. Trevisani M, Siemens J, Materazzi S, Bautista DM, Nassini R, Campi B, Imamachi N, Andre E, Patacchini R, Cottrell GS, Gatti R, Basbaum Al, Bunnett NW, Julius D, Geppetti P: 4-Hydroxynonenal, an endogenous aldehyde, causes pain and neurogenic inflammation through activation of the irritant receptor TRPAI. Proc Natl Acad Sci USA 2007, 104:13519-24.

\section{FlOOOPrime RECOMMENDED}

206. Van Steenwinckel J, Reaux-Le Goazigo A, Pommier B, Mauborgne A, Dansereau MA, Kitabgi P, Sarret P, Pohl M, Mélik Parsadaniantz S: CCL2 released from neuronal synaptic vesicles in the spinal cord is a major mediator of local inflammation and pain after peripheral nerve injury. J Neurosci 20II, 31:5865-75.

207. Hulsebosch CE, Hains BC, Crown ED, Carlton SM: Mechanisms of chronic central neuropathic pain after spinal cord injury. Brain Res Rev 2009, 60:202-13.

208. ladarola MJ, Brady LS, Draisci G, Dubner R: Enhancement of dynorphin gene expression in spinal cord following experimental inflammation: stimulus specificity, behavioral parameters and opioid receptor binding. Pain 1988, 35:3 13-26.
209. Malan TP, Ossipov MH, Gardell LR, Ibrahim M, Bian D, Lai J, Porreca F: Extraterritorial neuropathic pain correlates with multisegmental elevation of spinal dynorphin in nerveinjured rats. Pain 2000, 86: $185-94$.

210. Vanderah TW, Gardell LR, Burgess SE, Ibrahim M, Dogrul A, Zhong CM, Zhang ET, Malan TP, Ossipov MH, Lai J, Porreca F: Dynorphin promotes abnormal pain and spinal opioid antinociceptive tolerance. J Neurosci 2000, 20:7074-9.

211. Svensson $\mathrm{Cl}$, Hua X-Y, Powell HC, Lai J, Porreca F, Yaksh TL: Prostaglandin E2 release evoked by intrathecal dynorphin is dependent on spinal p38 mitogen activated protein kinase. Neuropeptides 2005, 39:485-94.

212. Wahlert A, Funkelstein L, Fitzsimmons B, Yaksh T, Hook V: Spinal astrocytes produce and secrete dynorphin neuropeptides. Neuropeptides 2013, 47:109-15.

213. Xin WJ, Weng HR, Dougherty PM: Plasticity in expression of the glutamate transporters GLT-I and GLAST in spinal dorsal horn glial cells following partial sciatic nerve ligation. Mol Pain 2009, 5:15.

214. Ramos KM, Lewis MT, Morgan KN, Crysdale NY, Kroll JL, Taylor FR, Harrison JA, Sloane EM, Maier SF, Watkins LR: Spinal upregulation of glutamate transporter GLT-I by ceftriaxone: therapeutic efficacy in a range of experimental nervous system disorders. Neuroscience 2010, 169:1888-900.

215. Watkins L, Hutchinson MR, Johnson KW: Commentary on Landry et al.: "Propentofylline, a CNS glial modulator, does not decrease pain in post-herpetic neuralgia patients: in vitro evidence for differential responses in human and rodent microglia and macrophages". Exp Neurol 2012, 234:35I-3.

216. Plane JM, Shen Y, Pleasure DE, Deng W: Prospects for minocycline neuroprotection. Arch Neurol 2010, 67:1442-8.

217. Loram LC, Harrison JA, Sloane EM, Hutchinson MR, Sholar P, Taylor FR, Berkelhammer D, Coats BD, Poole S, Milligan ED, Maier SF, Rieger J, Watkins LR: Enduring reversal of neuropathic pain by a single intrathecal injection of adenosine $2 \mathrm{~A}$ receptor agonists: a novel therapy for neuropathic pain. J Neurosci 2009, 29:14015-25.

218. Loram LC, Taylor FR, Strand KA, Harrison JA, RzasaLynn R, Sholar P, Rieger J, Maier SF, Watkins LR: Intrathecal injection of adenosine 2A receptor agonists reversed neuropathic allodynia through protein kinase (PK)A/PKC signaling. Brain Behav Immun 2013, 33: II $2-22$

219. Chu YX, Zhang Y, Zhang YQ, Zhao ZQ: Involvement of microglial P2X7 receptors and downstream signaling pathways in long-term potentiation of spinal nociceptive responses. Brain Behav Immun 20I0, 24:I I76-89.

220. Clark AK, Staniland AA, Marchand F, Kaan TK, McMahon S, Malcangio M: P2X7-dependent release of interleukin-l beta and nociception in the spinal cord following lipopolysaccharide. J Neurosci 2010, 30:573-82.

22I. He WJ, Cui J, Du L, Zhao YD, Burnstock G, Zhou HD, Ruan HZ: Spinal P2X(7) receptor mediates microglia activationinduced neuropathic pain in the sciatic nerve injury rat model. Behav Brain Res 2012, 226:163-70.

222. Kobayashi K, Yamanaka H, Fukuoka T, Dai Y, Obata K, Noguchi K: P2YI 2 receptor upregulation in activated microglia is a gateway of p38 signaling and neuropathic pain. J Neurosci 2008, 28:2892-902

223. Tozaki-Saitoh H, Tsuda M, Miyata H, Ueda K, Kohsaka S, Inoue K: P2YI2 receptors in spinal microglia are required for neuropathic pain after peripheral nerve injury. $J$ Neurosci 2008, 28:4949-56.

224. Svensson $\mathrm{Cl}$, Fitzsimmons B, Azizi S, Powell HC, Hua XY, Yaksh TL: Spinal p38beta isoform mediates tissue injury-induced hyperalgesia and spinal sensitization. J Neurochem 2005, 92:1508-20.

225. Anand P, Shenoy R, Palmer JE, Baines AJ, Lai RY, Robertson J, Bird N, Ostenfeld T, Chizh BA: Clinical trial of the p38 MAP kinase inhibitor dilmapimod in neuropathic pain following nerve injury. Eur J Pain 2011, 15:1040-8. 
226. Saijo K, Crotti A, Glass CK: Regulation of microglia activation and deactivation by nuclear receptors. Glia 2013, 6I:104-II.

227. Bettoni I, Comelli F, Rossini C, Granucci F, Giagnoni G, Peri F, Costa B: Glial TLR4 receptor as new target to treat neuropathic pain: Efficacy of a new receptor antagonist in a model of peripheral nerve injury in mice. Glia 2008, 56:1312-9.

228. Hutchinson MR, Zhang $Y$, Brown K, Coats BD, Shridhar M, Sholar PW, Patel SJ, Crysdale NY, Harrison JA, Maier SF, Rice KC, Watkins LR: Non-stereoselective reversal of neuropathic pain by naloxone and naltrexone: involvement of toll-like receptor 4 (TLR4). Eur J Neurosci 2008, 28:20-9.

\section{FIOOOPrime}

229. Christianson CA, Dumlao DS, Stokes JA, Dennis EA, Svensson Cl, Corr M, Yaksh TL: Spinal TLR4 mediates the transition to a persistent mechanical hypersensitivity after the resolution of inflammation in serum-transferred arthritis. Pain 2011, |52:288|-9|.

230. Kuang X, Huang Y, Gu HF, Zu XY, Zou WY, Song ZB, Guo QL: Effects of intrathecal epigallocatechin gallate, an inhibitor of Toll-like receptor 4, on chronic neuropathic pain in rats. Eur J Pharmacol 20I2, 676:5I-6.

23I. Zhang J, Shi XQ, Echeverry S, Mogil JS, De Koninck Y, Rivest S: Expression of CCR2 in both resident and bone marrowderived microglia plays a critical role in neuropathic pain. J Neurosci 2007, 27: 12396-406.

232. Echeverry S, Shi XQ, Rivest S, Zhang J: Peripheral Nerve Injury Alters Blood-Spinal Cord Barrier Functional and Molecular Integrity through a Selective Inflammatory Pathway. J Neurosci 201I, 31 : 10819-28.

233. Beggs S, Liu XJ, Kwan C, Salter MW: Peripheral nerve injury and TRPV I-expressing primary afferent $C$-fibers cause opening of the blood-brain barrier. Mol Pain 2010, 6:74.

\section{FlOOOPrime} RECOMMENDED

234. Suzuki R, Morcuende $S$, Webber $M$, Hunt SP, Dickenson $A H$ : Superficial NKI-expressing neurons control spinal excitability through activation of descending pathways. Nat Neurosci 2002, 5:1319-26.

235. Suzuki R, Dickenson A: Spinal and supraspinal contributions to central sensitization in peripheral neuropathy. Neurosignals 2005, | 4:|75-8|.

236. Svensson $\mathrm{Cl}$, Tran TK, Fitzsimmons B, Yaksh TL, Hua XY: Descending serotonergic facilitation of spinal ERK activation and pain behavior. FEBS Lett 2006, 580:6629-34

237. Wei F, Dubner R, Zou S, Ren K, Bai G, Wei D, Guo W: Molecular depletion of descending serotonin unmasks its novel facilitatory role in the development of persistent pain. J Neurosci 2010, 30:8624-36.

\section{FlOOOPrime}

\section{RECOMMENDED}

238. Peters CM, Hayashida K, Ewan EE, Nakajima K, Obata $H, X u Q$, Yaksh TL, Eisenach JC: Lack of analgesic efficacy of spinal ondansetron on thermal and mechanical hypersensitivity following spinal nerve ligation in the rat. Brain Res 2010 , 1352:83-93.

239. Godinez-Chaparro B, Lopez-Santillan FJ, Orduna P, Granados-Soto V: Secondary mechanical allodynia and hyperalgesia depend on descending facilitation mediated by spinal 5-HT(4), 5-HT(6) and 5-HT(7) receptors. Neuroscience 20I2, 222:379-9I.

240. Daniele CA, MacDermott AB: Low-threshold primary afferent drive onto GABAergic interneurons in the superficial dorsal horn of the mouse. J Neurosci 2009, 29:686-95.

24I. Bardoni R, Takazawa T, Tong CK, Choudhury P, Scherrer G, Macdermott AB: Pre- and postsynaptic inhibitory control in the spinal cord dorsal horn. Ann N Y Acad Sci 2013, 1279:90-6.
242. Mercier MS, Lodge D: Group III Metabotropic Glutamate Receptors: Pharmacology, Physiology and Therapeutic Potential. Neurochem Res 2014, 39:1876-94.

243. Goudet C, Chapuy E, Alloui A, Acher F, Pin JP, Eschalier A: Group III metabotropic glutamate receptors inhibit hyperalgesia in animal models of inflammation and neuropathic pain. Pain 2008, 137:1 12-24

244. Osikowicz M, Mika J, Makuch W, Przewlocka B: Glutamate receptor ligands attenuate allodynia andhyperalgesia and potentiate morphine effects in a mouse model of neuropathic pain. Pain 2008, 139:1 17-26.

245. Pertovaara A: The noradrenergic pain regulation system: a potential target for pain therapy. Eur J Pharmacol 2013, 716:2-7.

246. Tyce GM, Yaksh TL: Monoamine release from cat spinal cord by somatic stimuli: an intrinsic modulatory system. J Physiol I98I, 314:513-29.

247. Yaksh TL: Pharmacology of Spinal Adrenergic Systems Which Modulate Spinal Nociceptive Processing. Pharmacol Biochem Behav 1985, 22:845-58.

248. Ransohoff RM, Perry VH: Microglial physiology: unique stimuli, specialized responses. Annu Rev Immunol 2009, 27: I 19-45.

249. Waterman RS, Tomchuck SL, Henkle SL, Betancourt AM: A New Mesenchymal Stem Cell (MSC) Paradigm: Polarization into a Pro-Inflammatory MSCI or an Immunosuppressive MSC2 Phenotype. PLoS One 2010, 5(4).

FlOOOPrime

250. Waterman RS, Morgenweck J, Nossaman BD, Scandurro AE, Scandurro SA, Betancourt AM: Anti-inflammatory mesenchymal stem cells (MSC2) attenuate symptoms of painful diabetic peripheral neuropathy. Stem Cells Transl Med 2012, 1:557-65.

\section{FlOOOPrime} RECOMMENDED

25I. Austin PJ, Kim CF, Perera CJ, Moalem-Taylor G: Regulatory T cells attenuate neuropathic pain following peripheral nerve injury and experimental autoimmune neuritis. Pain 2012, I53:1916-3|.

252. Tsuda M, Masuda T, Kitano J, Shimoyama H, Tozaki-Saitoh H, Inoue K: IFN-gamma receptor signaling mediates spinal microglia activation driving neuropathic pain. Proc Natl Acad Sci USA 2009, 106:8032-7.

253. Costigan M, Moss A, Latremoliere A, Johnston C, Verma-Gandhu M, Herbert TA, Barrett L, Brenner GJ, Vardeh D, Woolf CJ, Fitzgerald M: T-Cell Infiltration and Signaling in the Adult Dorsal Spinal Cord Is a Major Contributor to Neuropathic Pain-Like Hypersensitivity. J Neurosci 2009, 29: I44I5-22.

254. Leger T, Grist J, D'Acquisto F, Clark AK, Malcangio M: Glatiramer acetate attenuates neuropathic allodynia through modulation of adaptive immune cells. J Neuroimmunol 20II, 234:19-26.

255. Pleticha J, Malkmus SA, Heilmann LF, Veesart SL, Rezek R, Xu Q, Yaksh TL, Beutler AS: High cerebrospinal fluid levels of interleukin-10 attained by AAV in dogs. Gene Ther 2014.

256. He ZH, Guo QL, Xiao MZ, He CL, Zou WY: Intrathecal Lentivirus-mediated Transfer of Interleukin-10 Attenuates Chronic Constriction Injury-induced Neuropathic Pain through Modulation of Spinal High-mobility Group Box I in Rats. Pain Physician 2013, I6:E615-25.

257. Soderquist RG, Sloane EM, Loram LC, Harrison JA, Dengler EC, Johnson SM, Amer LD, Young CS, Lewis MT, Poole S, Frank MG, Watkins LR, Milligan ED, Mahoney MJ: Release of plasmid DNAencoding IL-I 0 from PLGA microparticles facilitates long-term reversal of neuropathic pain following a single intrathecal administration. Pharm Res 2010, 27:841-54.

\section{FlOOOPrime}

RECOMMENDED

258. Milligan ED, Penzkover KR, Soderquist RG, Mahoney MJ: Spinal interleukin- 10 therapy to treat peripheral neuropathic pain. Neuromodulation 2012, 15:520-6; discussion 526. 
259. Ji RR, Xu ZZ, Strichartz G, Serhan CN: Emerging roles of resolvins in the resolution of inflammation and pain. Trends Neurosci 201 I, 34:599-609.

260. Xu ZZ, Zhang L, Liu T, Park JY, Berta T, Yang R, Serhan CN, Ji RR: Resolvins RvEI and RvDI attenuate inflammatory pain via central and peripheral actions. Nat Med 2010, 16:592-7.

\section{FlOOOPrime} RECOMMENDE

26I. Lima-Garcia JF, Dutra RC, da Silva K, Motta EM, Campos MM, Calixto JB: The precursor of resolvin $D$ series and aspirin-triggered resolvin DI display anti-hyperalgesic properties in adjuvantinduced arthritis in rats. Br J Pharmacol 20II, 164:278-93.

\section{FIOOOPRime}

262. Xu ZZ, Liu XJ, Berta T, Park CK, Lu N, Serhan CN, Ji RR: Neuroprotectin/protectin DI protects against neuropathic pain in mice after nerve trauma. Ann Neurol 2013, 74:490-5.

263. Xu ZZ, Berta T, Ji RR: Resolvin El inhibits neuropathic pain and spinal cord microglial activation following peripheral nerve injury. J Neuroimmune Pharmacol 2013, 8:37-4I.

264. Inceoglu B, Jinks SL, Ulu A, Hegedus CM, Georgi K, Schmelzer KR, Wagner K, Jones PD, Morisseau C, Hammock BD: Soluble epoxide hydrolase and epoxyeicosatrienoic acids modulate two distinct analgesic pathways. Proc Natl Acad Sci USA 2008, 105:1890I-6.

265. Morisseau C, Inceoglu B, Schmelzer K, Tsai HJ, Jinks SL, Hegedus CM, Hammock BD: Naturally occurring monoepoxides of eicosapentaenoic acid and docosahexaenoic acid are bioactive antihyperalgesic lipids. J Lipid Res 2010, 5 I:348I-90.

266. Williams JT, Ingram SL, Henderson G, Chavkin C, von Zastrow M, Schulz S, Koch T, Evans CJ, Christie MJ: Regulation of mu-opioid receptors: desensitization, phosphorylation, internalization, and tolerance. Pharmacol Rev 2013, 65:223-54.

267. Law PY, Reggio PH, Loh HH: Opioid receptors: toward separation of analgesic from undesirable effects. Trends Biochem Sci 2013, 38:275-82.

268. Yaksh TL: Pharmacology and mechanisms of opioid analgesic activity. Acta Anaesthesiol Scand 1997, 41:94-III.

269. Dickenson AH: Mechanisms of the analgesic actions of opiates and opioids. Br Med Bull 1991, 47:690-702.

270. Kosarac B, Fox AA, Collard CD: Effect of genetic factors on opioid action. Curr Opin Anaesthesiol 2009, 22:476-82.

27I. Majumdar S, Grinnell S, Le Rouzic V, Burgman M, Polikar L, Ansonoff M, Pintar J, Pan YX, Pasternak GW: Truncated G protein-coupled mu opioid receptor MOR-I splice variants are targets for highly potent opioid analgesics lacking side effects. Proc Natl Acad Sci USA 20I I, 108:19778-83.

272. Kenakin T: Functional selectivity and biased receptor signaling. J Pharmacol Exp Ther 2011, 336:296-302.

273. Raehal KM, Bohn LM: The role of beta-arrestin 2 in the severity of antinociceptive tolerance and physical dependence induced by different opioid pain therapeutics. Neuropharmacology 20II, 60:58-65.

274. Chen XT, Pitis P, Liu G, Yuan C, Gotcher D, Cowan CL, Rominger DH, Koblish M, Dewire SM, Crombie AL, Violin JD, Yamashita DS: Structure-activity relationships and discovery of a G protein biased mu opioid receptor ligand, [(3-methoxythiophen-2-yl)methyl] (\{2-[(9R)-9-(pyridin-2-yl)-6-oxaspiro[4.5]decan- 9-yl] ethyl\}) amine (TRV I30), for the treatment of acute severe pain. J Med Chem 2013, 56:8019-31.

275. Violin JD, Crombie AL, Soergel DG, Lark MW: Biased ligands at G protein-coupled receptors: promise and progress. Trends Pharmacol Sci 2014, 35:308-16.

276. Gomes I, Gupta A, Filipovska J, Szeto HH, Pintar JE, Devi LA: A role for heterodimerization of $\mathrm{mu}$ and delta opiate receptors in enhancing morphine analgesia. Proc Natl Acad Sci USA 2004, 101:5135-9.
277. Lenard NR, Daniels DJ, Portoghese PS, Roerig SC: Absence of conditioned place preference or reinstatement with bivalent ligands containing mu-opioid receptor agonist and deltaopioid receptor antagonist pharmacophores. Eur J Pharmacol 2007, 566:75-82.

\section{FlOOOPrime}

RECOMMENDED

278. Le Naour M, Akgün E, Yekkirala A, Lunzer MM, Powers MD, Kalyuzhny $A E$, Portoghese PS: Bivalent ligands that target $\mu$ opioid (MOP) and cannabinoid I (CBI) receptors are potent analgesics devoid of tolerance. J Med Chem 2013, 56:5505-13.

279. Akgün E, Javed MI, Lunzer MM, Smeester BA, Beitz AJ, Portoghese PS: Ligands that interact with putative MOR-mGluR5 heteromer in mice with inflammatory pain produce potent antinociception. PNAS 2013, II 0:1 I595-9.

\section{FlOOOPrime
RECOMMENDED}

280. Smeester BA, Lunzer MM, Akgun E, Beitz AJ, Portoghese PS: Targeting putative $\mathrm{mu}$ opioid/metabotropic glutamate receptor-5 heteromers produces potent antinociception in a chronic murine bone cancer model. Eur J Pharmacol 2014.

28I. Daniels DJ, Lenard NR, Etienne CL, Law PY, Roerig SC, Portoghese PS: Opioid-induced tolerance and dependence in mice is modulated by the distance between pharmacophores in a bivalent ligand series. P Natl Acad Sci USA 2005, 102: 19208-13.

\section{FlOOOPrime}

RECOMMENDED

282. Brede M, Philipp M, Knaus A, Muthig V, Hein L: alpha2-adrenergic receptor subtypes - novel functions uncovered in genetargeted mouse models. Biol Cell 2004, 96:343-8.

283. Chrysostomou C, Schmitt CG: Dexmedetomidine: sedation, analgesia and beyond. Expert Opin Drug Metab Toxicol 2008, 4:619-27.

284. Paddleford RR, Harvey RC: Alpha 2 agonists and antagonists. Vet Clin North Am Small Anim Pract 1999, 29:737-45.

285. Gilsbach R, Hein L: Are the pharmacology and physiology of $\alpha_{2}$ adrenoceptors determined by $\alpha_{2}$-heteroreceptors and autoreceptors respectively? $\mathrm{Br}$ J Pharmacol 2012, 165:90-102.

286. Boccia ML, Petrusz P, Suzuki K, Marson L, Pedersen CA: Immunohistochemical localization of oxytocin receptors in human brain. Neuroscience 2013, 253:155-64.

287. Gonzalez-Hernandez A, Rojas-Piloni G, Condes-Lara M: Oxytocin and analgesia: future trends. Trends Pharmacol Sci 2014.

288. Qiu F, Qiu CY, Cai HL, Liu TT, Qu ZW, Yang ZF, Li JD, Zhou QY, Hu WP: Oxytocin inhibits the activity of acid-sensing ion channels through the vasopressin, VIA receptor in primary sensory neurons. Brit J Pharmacol 2014, I7 I:3065-76.

289. Yu SQ, Lundeberg T, Yu LC: Involvement of oxytocin in spinal antinociception in rats with inflammation. Brain Res 2003, 983:13-22.

290. Breton JD, Veinante P, Uhl-Bronner S, Vergnano AM, FreundMercier MJ, Schlichter R, Poisbeau P: Oxytocin-induced antinociception in the spinal cord is mediated by a subpopulation of glutamatergic neurons in lamina I-II which amplify GABAergic inhibition. Mol Pain 2008, 4.

29I. Dhopeshwarkar A, Mackie K: CB2 Cannabinoid receptors as a therapeutic target-what does the future hold? Mol Pharmacol, 86:430-7.

292. Volkow ND, Baler RD, Compton WM, Weiss SRB: Adverse Health Effects of Marijuana Use. New England Journal of Medicine 2014, $370: 2219-27$

293. Deng L, Guindon J, Cornett BL, Makriyannis A, Mackie K, Hohmann AG: Chronic cannabinoid receptor 2 activation reverses paclitaxel neuropathy without tolerance or cannabinoid receptor I-dependent withdrawal. Biol Psych 2014, [Epub ahead of print]. 
294. Morisset V, Ahluwalia J, Nagy I, Urban L: Possible mechanisms of cannabinoid-induced antinociception in the spinal cord. Eur J Pharmacol 2001, 429:93-100.

295. Ehrhart J, Obregon D, Mori T, Hou H, Sun N, Bai Y, Klein T, Fernandez F, Tan J, Shytle RD: Stimulation of cannabinoid receptor 2 (CB2) suppresses microglial activation. J Neuroinflammation 2005, 2:29.

296. Guindon J, Hohmann AG: The endocannabinoid system and pain. CNS Neurol Disord Drug Targets 2009, 8:403-2I.

297. Davis MP: Cannabinoids in pain management: $C B I, C B 2$ and non-classic receptor ligands. Expert Opin Investig Drugs 2014, 23: I I 23-40.

298. Piomelli D: More surprises lying ahead. The endocannabinoids keep us guessing. Neuropharmacology 2014.

299. Wiley RG: Substance $\mathbf{P}$ receptor-expressing dorsal horn neurons: lessons from the targeted cytotoxin, substance Psaporin. Pain 2008, 136:7-10.

\section{FlOOOPrime} RECOMMENDED

300. Wiese AJ, Rathbun M, Butt MT, Malkmus SA, Richter PJ, Osborn KG, Xu Q, Veesart SL, Steinauer JJ, Higgins D, Lappi DA, Russell B, Yaksh TL: Intrathecal substance P-saporin in the dog: distribution, safety, and spinal neurokinin-I receptor ablation. Anesthesiology 2013, I | 9: I | 63-77.

301. Brown DC, Agnello K: Intrathecal substance P-saporin in the dog: efficacy in bone cancer pain. Anesthesiology 2013, I I 9: I I78-85.

302. Mustafa G, Anderson EM, Bokrand-Donatelli Y, Neubert JK, Caudle RM: Anti-nociceptive effect of a conjugate of substance $\mathbf{P}$ and light chain of botulinum neurotoxin type A. Pain 2013, I 54:2547-53.

\section{FlOOOPrime}

\section{RECOMMENDED}

303. Brown DC, ladarola MJ, Perkowski SZ, Erin H, Shofer F, Laszlo KJ, Olah Z, Mannes AJ: Physiologic and antinociceptive effects of intrathecal resiniferatoxin in a canine bone cancer model. Anesthesiology 2005, I03:1052-9.

304. Bevan S, Quallo T, Andersson DA: Trpvl. Handb Exp Pharmacol 20।4, 222:207-45.

305. Kissin I, Szallasi A: Therapeutic targeting of TRPVI by resiniferatoxin, from preclinical studies to clinical trials. Curr Top Med Chem 201 I, I I:2159-70.

306. Puopolo M, Binshtok AM, Yao GL, Oh SB, Woolf CJ, Bean BP: Permeation and block of TRPVI channels by the cationic lidocaine derivative QX-3 I4. J Neurophysiol 2013, 109: I704-I2.

\section{FlOOOPrime \\ RECOMMENDED}

307. Rohl T, Kurreck J: RNA interference in pain research. J Neurochem 2006, 99:37I-80

308. Dominguez E, Meunier A, Pohl M: Gene-based approaches in the study of pathological pain. Methods Mol Biol 2010, 61 7:297-308.

309. Molet J, Pohl M: Gene-based approaches in pain research and exploration of new therapeutic targets and strategies. Eur J Pharmacol 2013, 7 I6:129-4I.

310. Hua XY, Chen P, Polgar E, Nagy I, Marsala M, Phillips E, Wollaston L, Urban L, Yaksh TL, Webb M: Spinal neurokinin NKI receptor down-regulation and antinociception: effects of spinal NKI receptor antisense oligonucleotides and NKI receptor occupancy. J Neurochem 1998, 70:688-98.

3II. Tan PH, Yang LC, Shih HC, Lan KC, Cheng JT: Gene knockdown with intrathecal siRNA of NMDA receptor NR2B subunit reduces formalin-induced nociception in the rat. Gene Ther 2005, I 2:59-66.

3I2. Dorn G, Abdel'AI S, Natt FJ, Weiler J, Hall J, Meigel I, Mosbacher J, Wishart W: Specific inhibition of the rat ligand-gatedion channel P2X3 function via methoxyethoxy-modified phosphorothioated antisense oligonucleotides. Antisense Nucl Acid Drug Dev 2001, I I: I65-74.
3I3. Wu ZZ, Yang Q, Crook RJ, O'Neil RG, Walters ET: TRPVI channels make major contributions to behavioral hypersensitivity and spontaneous activity in nociceptors after spinal cord injury. Pain 2013, 154:2130-4I.

314. Fitzsimmons BL, Zattoni $M$, Svensson $\mathrm{Cl}$, Steinauer J, Hua XY, Yaksh TL: Role of spinal p38alpha and beta MAPK in inflammatory hyperalgesia and spinal COX-2 expression. Neuroreport 2010, $21: 313-7$.

315. Kim DH, Fitzsimmons B, Hefferan MP, Svensson Cl, Wancewicz E, Monia BP, Hung G, Butler M, Marsala M, Hua XY, Yaksh TL: Inhibition of spinal cytosolic phospholipase $A(2)$ expression by an antisense oligonucleotide attenuates tissue injury-induced hyperalgesia. Neuroscience 2008, I 54:1077-87.

316. Lai J, Gold MS, Kim CS, Bian D, Ossipov MH, Hunter JC, Porreca F: Inhibition of neuropathic pain by decreased expression of the tetrodotoxin-resistant sodium channel, NaVI.8. Pain 2002, 95: $143-52$.

317. Guo W, Robbins MT, Wei F, Zou S, Dubner R, Ren K: Supraspinal brain-derived neurotrophic factor signaling: a novel mechanism for descending pain facilitation. J Neurosci 2006, 26:126-37.

\section{FlOOOPrime}

\section{RECOMMENDED}

318. Chattopadhyay M, Zhou Z, Hao S, Mata M, Fink DJ: Reduction of voltage gated sodium channel protein in DRG by vector mediated miRNA reduces pain in rats with painful diabetic neuropathy. Mol Pain 2012, 8:17.

319. Storek B, Reinhardt M, Wang C, Janssen WG, Harder NM, Banck MS, Morrison JH, Beutler AS: Sensory neuron targeting by selfcomplementary AAV8 via lumbar puncture for chronic pain. Proc Natl Acad Sci U S A 2008, I05: 1055-60.

\section{FlOOOPrime}

\section{RECOMMENDED}

320. Wu F, Xu X, Miao X, Chen J, Sun Y, Yu W: Effect of recombinant adenovirus coding for endomorphin-2 on neuropathic pain in rats. Int J Clin Exp Pathol 2012, 5:9|4-23.

321. Tzabazis AZ, Klukinov M, Feliciano DP, Wilson SP, Yeomans DC: Gene therapy for trigeminal pain in mice. Gene Ther 2014, 21:422-6.

322. Milligan ED, Sloane EM, Langer SJ, Cruz PE, Chacur M, Spataro L, Wieseler-Frank J, Hammack SE, Maier SF, Flotte TR, Forsayeth JR, Leinwand LA, Chavez R, Watkins LR: Controlling neuropathic pain by adeno-associated virus driven production of the antiinflammatory cytokine, interleukin- I0. Mol Pain 2005, I:9.

323. Ndong C, Landry RP, DeLeo JA, Romero-Sandoval EA: Mitogen activated protein kinase phosphatase-I prevents the development of tactile sensitivity in a rodent model of neuropathic pain. Mol Pain 20I2, 8:34.

324. Fischer G, Pan B, Vilceanu D, Hogan QH, Yu H: Sustained relief of neuropathic pain by AAV-targeted expression of CBD3 peptide in rat dorsal root ganglion. Gene Ther 2014, 2 I:44-5I.

325. Fan L, Guan X, Wang W, Zhao JY, Zhang H, Tiwari V, Hoffman PN, $\mathrm{Li} M$, Tao $Y X$ : Impaired neuropathic pain and preserved acute pain in rats overexpressing voltage-gated potassium channel subunit KvI.2 in primary afferent neurons. Mol Pain 20I4, I0:8.

326. Yaksh TL: Spinal Delivery and Assessment of Drug Safety. In Fundamental Neuropathology for Pathologists and Toxicologists: Principles and Techniques. Edited by Bolon B, Butt M. New Jersey: WileyBlackwell; 201 I:451-62.

327. Hayek SM, Hanes MC: Intrathecal therapy for chronic pain: current trends and future needs. Curr Pain Headache Rep 2014, I 8:388.

328. Grouls RJE KE, Yaksh TL: General considerations for the formulation of drugs for spinal delivery. In Spinal Drug Delivery. Edited by Yaksh TL. Amsterdam: Elsevier Science B.V.; 1999:371-93.

329. Hadley G, Derry S, Moore RA, Wiffen PJ: Transdermal fentanyl for cancer pain. Cochrane Database Syst Rev 2013, I0:CD0 0270. 
330. Derry S, Sven-Rice A, Cole P, Tan T, Moore RA: Topical capsaicin (high concentration) for chronic neuropathic pain in adults. Cochrane Database Syst Rev 2013, 2:CD007393.

33I. Peppin JF, Pappagallo M: Capsaicinoids in the treatment of neuropathic pain: a review. Ther Adv Neurol Disord 2014, 7:22-32.

332. Wolff RF, Bala MM, Westwood M, Kessels AG, Kleijnen J: $\mathbf{5 \%}$ lidocaine-medicated plaster vs other relevant interventions and placebo for post-herpetic neuralgia (PHN): a systematic review. Acta Neurol Scand 20I I, I 23:295-309.

333. Stanos SP, Galluzzi KE: Topical therapies in the management of chronic pain. Postgrad Med 2013, I 25(Suppl I):25-33.

334. Matak I, Bach-Rojecky L, Filipovic B, Lackovic Z: Behavioral and immunohistochemical evidence for central antinociceptive activity of botulinum toxin A. Neuroscience 201I, 186:201-7.

335. Marino MJ, Terashima T, Steinauer JJ, Eddinger KA, Yaksh TL, Xu Q: Botulinum toxin $B$ in the sensory afferent: transmitter release, spinal activation, and pain behavior. Pain 20I4, 155:674-84.

336. Marchand-Pauvert V, Aymard C, Giboin LS, Dominici F, Rossi A, Mazzocchio R: Beyond muscular effects: depression of spinal recurrent inhibition after botulinum neurotoxin A. J Physiol 2013, 59I:1017-29.

337. Marinelli S, Vacca V, Ricordy R, Uggenti C, Tata AM, Luvisetto S, Pavone F: The analgesic effect on neuropathic pain of retrogradely transported botulinum neurotoxin A involves Schwann cells and astrocytes. PLoS One 2012, 7:e47977.

338. Filipovic B, Matak I, Bach-Rojecky L, Lackovic Z: Central action of peripherally applied botulinum toxin type $A$ on pain and dural protein extravasation in rat model of trigeminal neuropathy. PLoS One 2012, 7:e29803.

339. Carmichael NM, Dostrovsky JO, Charlton MP: Peptide-mediated transdermal delivery of botulinum neurotoxin type $A$ reduces neurogenic inflammation in the skin. Pain 2010, 149:316-24

340. Tuan-Mahmood TM, McCrudden MT, Torrisi BM, McAlister E, Garland MJ, Singh TR, Donnelly RF: Microneedles for intradermal and transdermal drug delivery. Eur J Pharm Sci 20I3, 50:623-37.

34I. Crosera M, Bovenzi M, Maina G, Adami G, Zanette C, Florio C, Filon Larese F: Nanoparticle dermal absorption and toxicity: a review of the literature. Int Arch Occup Environ Health 2009, 82:1043-55.

342. Smijs TGM, Bouwstra JA: Focus on Skin as a Possible Port of Entry for Solid Nanoparticles and the Toxicological Impact. J Biomed Nanotechnol 2010, 6:469-84.

343. Ito Y, Kashiwara S, Fukushima K, Takada K: Two-layered dissolving microneedles for percutaneous delivery of sumatriptan in rats. Drug Dev Ind Pharm 20II, 37:1387-93.

344. Zhang Y, Siebenaler K, Brown K, Dohmeier D, Hansen K: Adjuvants to prolong the local anesthetic effects of coated microneedle products. Int J Pharm 20I2, 439:187-92.

345. Prausnitz MR, Bose VG, Langer R, Weaver JC: Electroporation of Mammalian Skin - a Mechanism to Enhance Transdermal Drug-Delivery. P Natl Acad Sci USA 1993, 90:10504-8.

346. Roxhed N, Samel B, Nordquist L, Griss P, Stemme G: Painless drug delivery through microneedle-based transdermal patches featuring active infusion. IEEE Trans Biomed Eng 2008, 55:1063-7I.

347. Escobar-Chavez JJ, Bonilla-Martinez D, Villegas-Gonzalez MA, RevillaVazquez AL: Electroporation as an Efficient Physical Enhancer for Skin Drug Delivery. J Clin Pharmacol 2009, 49:1262-83.

348. Lee JW, Park JH, Robinson JR: Bioadhesive-based dosage forms: the next generation. J Pharm Sci 2000, 89:850-66.

349. Smart JD: The basics and underlying mechanisms of mucoadhesion. Adv Drug Deliv Rev 2005, 57:1556-68.

350. Andrews GP, Laverty TP, Jones DS: Mucoadhesive polymeric platforms for controlled drug delivery. Eur J Pharm Biopharm 2009, 71:505-18.

35I. Jandhyala R, Fullarton JR, MI B: Efficacy of rapid-onset oral fentanyl formulations vs. oral morphine for cancer-related breakthrough pain: a meta-analysis of comparative trials. J Pain Symptom Manage 2013, 46:573-80.

352. Djupesland PG, Messina JC, Mahmoud RA: The nasal approach to delivering treatment for brain diseases: an anatomic, physiologic, and delivery technology overview. Ther Deliv 2014, 5:709-33.

353. Campbell C, Morimoto BH, Nenciu D, Fox AW: Drug development of intranasally delivered peptides. Ther Deliv 2012, 3:557-68

354. Prego C, Garcia M, Torres D, Alonso MJ: Transmucosal macromolecular drug delivery. J Control Release 2005, 101:151-62.

355. Westin U, Piras E, Jansson B, Bergstrom U, Dahlin M, Brittebo E, Bjork $E$ : Transfer of morphinealong the olfactory pathway to the central nervoussystem after nasal administration to rodents. Eur J Pharm Sci 2005, 24:565-73.

356. Pardeshi CV, Belgamwar VS: Direct nose to brain drug delivery via integrated nerve pathways bypassing the blood-brain barrier: an excellent platform for brain targeting. Expert Opin Drug Deliv 2013, 10:957-72.

357. Wang YL, Yuan Y, Yang J, Wang CH, Pan YJ, Lu L, Wu YQ, Wang DX, Lv LX, Li RR, et al.: The interaction between the oxytocin and pain modulation in headache patients. Neuropeptides 2013, 47:93-7.

358. Goodin BR, Anderson AJ, Freeman EL, Bulls HW, Robbins MT, Ness TJ: Intranasal Oxytocin Administration is Associated with Enhanced Endogenous Pain Inhibition and Reduced Negative Mood States. Clin J Pain 2014.

359. Chen YF, Jobanputra P, Barton P, Bryan S, Fry-Smith A, Harris G, Taylor RS: Cyclooxygenase-2 selective non-steroidal antiinflammatory drugs (etodolac, meloxicam, celecoxib, rofecoxib, etoricoxib, valdecoxib and lumiracoxib) for osteoarthritis and rheumatoid arthritis: a systematic review and economic evaluation. Health Technol Assess 2008, I 2: I-278, iii.

360. Patrignani P, Patrono C: Cyclooxygenase inhibitors: From pharmacology to clinical read-outs. Biochim Biophys Acta 2014, | 85 I:422-432.

36I. Hinz B, Renner B, Brune K: Drug Insight: cyclo-oxygenase-2 inhibitors - a critical appraisal. Nature Clinical Practice Rheumatology 2007, 3:552-60.

362. Lewin GR, Rueff A, Mendell LM: Peripheral and central mechanisms of NGF-induced hyperalgesia. Eur J Neurosci 1994, 6:1903-12.

363. Sanga P, Katz N, Polverejan E, Wang S, Kelly K, Haeussler J, Thipphawong J: Efficacy, safety, and tolerability of fulranumab, an anti-nerve growth factor antibody, in the treatment of patients with moderate to severe osteoarthritis pain. Pain 2013 , 154:1910-9.

364. Bannwarth B, Kostine M: Targeting Nerve Growth Factor (NGF) for Pain Management: What Does the Future Hold for NGF Antagonists? Drugs 2014, 74:619-26.

365. Gearing DP, Virtue ER, Gearing RP, Drew AC: A fully caninised anti-NGF monoclonal antibody for pain relief in dogs. $B M C$ Vet Res 2013, 9:226.

\section{FlOOOPrime} RECOMMENDED

366. Hochberg MC: Serious joint-related adverse events in randomized controlled trials of anti-nerve growth factor monoclonal antibodies. Osteoarthritis Cartilage 2015, 23(Suppl I):SI8-2I.

367. Olivera BM, Cruz LJ, Desantos V, Lecheminant GW, Griffin D, Zeikus R, Mcintosh JM, Galyean R, Varga J, Gray WR et al.: Neuronal Calcium-Channel Antagonists - Discrimination between Calcium-Channel Subtypes Using Omega-Conotoxin from Conus-Magus Venom. Biochemistry 1987, 26:2086-90.

368. Gohil K, Bell JR, Ramachandran J, Miljanich GP: Neuroanatomical distribution of receptors for a novel voltage-sensitive calcium-channel antagonist, SNX-230 (omega-conopeptide MVIIC). Brain Res 1994, 653:258-66. 
369. Chaplan SR, Pogrel JW, Yaksh TL: Role of voltage-dependent calcium channel subtypes in experimental tactile allodynia. J Pharmacol Exp Ther 1994, 269:1 1 17-23.

370. Rahman W, Dickenson $\mathrm{AH}$ : Voltage gated sodium and calcium channel blockers for the treatment of chronic inflammatory pain. Neurosci Lett 2013, 557 Pt A:19-26.

37I. Sanford M: Intrathecal ziconotide: a review of its use in patients with chronic pain refractory to other systemic or intrathecal analgesics. CNS Drugs 2013, 27:989-1002.

372. Salat K, Kowalczyk P, Gryzlo B, Jakubowska A, Kulig K: New investigational drugs for the treatment of neuropathic pain. Expert Opin Investig Drugs 2014, 23:1093-104.

373. Tuchman M, Barrett JA, Donevan S, Hedberg TG, Taylor CP: Central sensitization and $\mathrm{Ca}(\mathrm{V}) \alpha_{2} \delta$ ligands in chronic pain syndromes: pathologic processes and pharmacologic effect. J Pain 2010, II:I24I-9.

374. Jacus MO, Uebele VN, Renger J], Todorovic SM: Presynaptic CaV channels regulate excitatory neurotransmission in nociceptive dorsal horn neurons. J Neurosci 20I2, 32:9374-8I.

\section{FlOOOPrime}

375. Wallace MS, Rowbotham MC, Bennett GJ, Jensen T, Pladna R, Quessy S: A multicenter, double-blind, randomized, placebocontrolled crossover evaluation of a short course of 4030W92 in patients with chronic neuropathic pain. J Pain 2002, 3:227-33.

376. Goldberg YP, Price N, Namdari R, Cohen CJ, Lamers MH, Winters C, Price J, Young CE, Verschoof $H$, Sherrington R, Pimstone SN, Hayden MR: Treatment of $\mathrm{Na}(\mathrm{v})$ I.7-mediated pain in inherited erythromelalgia using a novel sodium channel blocker. Pain 2012, I53:80-5.

377. Kohane DS, Lu NT, Gokgol-Kline AC, Shubina M, Kuang Y, Hall S, Strichartz GR, Berde CB: The local anesthetic properties and toxicity of saxitonin homologues for rat sciatic nerve block in vivo. Reg Anesth Pain Med 2000, 25:52-9.

378. Nieto FR, Cobos EJ, Tejada MA, Sanchez-Fernandez C, GonzalezCano R, Cendan CM: Tetrodotoxin (TTX) as a Therapeutic Agent for Pain. Marine Drugs 20I2, 10:28I-305.

379. Rodriguez-Navarro AJ, Berde CB, Wiedmaier G, Mercado A, Garcia C, Iglesias V, Zurakowski D: Comparison of neosaxitoxin versus bupivacaine via port infiltration for postoperative analgesia following laparoscopic cholecystectomy: a randomized, double-blind trial. Reg Anesth Pain Med 201I, 36:103-9.

\section{FlOOOPrime} RECOMMENDED

380. Smith MT, Woodruff TM, Wyse BD, Muralidharan A, Walther T: A small molecule angiotensin II type 2 receptor $\left(A T_{2} R\right)$ antagonist produces analgesia in a rat model of neuropathic pain by inhibition of p38 mitogen-activated protein kinase (MAPK) and p44/p42 MAPK activation in the dorsal root ganglia. Pain Med 2013, 14:1557-68.

38I. Smith MT, Wyse BD, Edwards SR: Small molecule angiotensin II type 2 receptor (ATR) antagonists as novel analgesics for neuropathic pain: comparative pharmacokinetics, radioligand binding, and efficacy in rats. Pain Med 2013, 14:692-705.

382. Rice AS, Dworkin RH, McCarthy TD, Anand P, Bountra C, McCloud P, Hill J, Cutter G, Kitson G, Desem N et al.: EMA40I, an orally administered highly selective angiotensin II type 2 receptor antagonist, as a novel treatment for postherpetic neuralgia: a randomised, double-blind, placebo-controlled phase 2 clinical tria. Lancet 2014, 383:1637-47.

\section{FIOOOPrime}

383. Gray AM, Pache DM, Sewell RD: Do alpha2-adrenoceptors play an integral role in the antinociceptive mechanism of action of antidepressant compounds? Eur J Pharmacol 1999, 378:161-8.

384. Smith EML, Pang H, Cirrincione C, Fleishman S, Paskett ED, Ahles T, Bressler LR, Fadul CE, Knox C, Le-Lindqwister N, Gilman PB,
Shapiro CL, Alliance for Clinical Trials in Oncology: Effect of Duloxetine on Pain, Function, and Quality of Life Among Patients With Chemotherapy-Induced Painful Peripheral Neuropathy A Randomized Clinical Trial. JAMA 2013, 309:1359-67.

\section{FlOOOPrime}

385. Sultan A, Gaskell H, Derry S, Moore RA: Duloxetine for painful diabetic neuropathy and fibromyalgia pain: systematic review of randomised trials. Bmc Neurology 2008, 8.

386. Wright CL, Mist SD, Ross RL, Jones KD: Duloxetine for the treatment of fibromyalgia. Expert Rev Clin Immunol 2010, 6:745-56.

387. Wong K, Phelan R, Kalso E, Galvin I, Goldstein D, Raja S, Gilron I: Antidepressant Drugs for Prevention of Acute and Chronic Postsurgical Pain Early Evidence and Recommended Future Directions. Anesthesiology 2014, I 2 1:591-608.

388. Hill R: NKI (substance $P$ ) receptor antagonists-why are they not analgesic in humans? Trends Pharmacol Sci 2000, 21:244-6.

389. Dionne RA, Max MB, Gordon SM, Parada S, Sang C, Gracely RH, Sethna NF, MacLean DB: The substance $P$ receptor antagonist CP-99,994 reduces acute postoperative pain. Clin Pharmacol Ther 1998, 64:562-8.

390. Wallace MS, Rowbotham MC, Katz NP, Dworkin RH, Dotson RM, Galer BS, Rauck RL, Backonja MM, Quessy SN, Meisner PD: A randomized, double-blind, placebo-controlled trial of a glycine antagonist in neuropathic pain. Neurology 2002, 59: 1694-700.

39I. Martinez V, Szekely B, Lemarie J, Martin F, Gentili M, Ben Ammar S, Lepeintre JF, Garreau de Loubresse C, Chauvin M, Bouhassira D, Fletcher D: The efficacy of a glial inhibitor, minocycline, for preventing persistent pain after lumbar discectomy: a randomized, double-blind, controlled study. Pain 2013, I54:1 197-203.

\section{FlOOOPrime
RECOMMENDED}

392. Ostenfeld T, Price J, Albanese M, Bullman J, Guillard F, Meyer I, Leeson R, Costantin C, Ziviani L, Nocini PF, Milleri S: A randomized, controlled study to investigate the analgesic efficacy of single doses of the cannabinoid receptor-2 agonist GW842166, ibuprofen or placebo in patients with acute pain following third molar tooth extraction. Clin J Pain 2011, 27:668-76.

393. Mogil JS: Animal models of pain: progress and challenges. Nat Rev Neurosci 2009, 10:283-94.

394. Ioannidis JPA: Why most published research findings are false. Plos Medicine 2005, 2:696-70I.

\section{FlOOOPrime}

395. van Laar M, Pergolizzi JV, Jr., Mellinghoff HU, Merchante IM, Nalamachu S, O'Brien J, Perrot S, Raffa RB: Pain treatment in arthritis-related pain: beyond NSAIDs. Open Rheumatol J 20I2, 6:320-30.

396. Lötsch J, Doehring A, Mogil JS, Arndt T, Geisslinger G, Ultsch A: Functional genomics of pain in analgesic drug development and therapy. Pharmacol Ther 2013, 139:60-70.

397. Trescot AM, Faynboym S: A Review of the Role of Genetic Testing in Pain Medicine. Pain Physician 2014, 17:425-45.

398. Kosharskyy B, Almonte W, Shaparin N, Pappagallo M, Smith H: Intravenous infusions in chronic pain management. Pain Physician 2013, 16:231-49.

399. Wang JG, Strong JA, Xie W, Yang RH, Coyle DE, Wick DM, Dorsey ED, Zhang JM: The chemokine CXCLI/growth related oncogene increases sodium currents and neuronal excitability in small diameter sensory neurons. Mol Pain 2008, 4:38.

400. Pasternak GW: Opioids and their receptors: Are we there yet? Neuropharmacology 2014, 76:198-203.

40I. Gaynor JS, Muir WW: Handbook of veterinary pain management. St. Louis: Mosby Inc; 2002. 
402. Quandt J: Analgesia, anesthesia, and chemical restraint in the emergent small animal patient. Vet Clin North Am Small Anim Pract 2013, 43:941-53.

403. Kwilasz AJ, Grace PM, Serbedzija P, Maier SF, Watkins LR: The therapeutic potential of interleukin-IO in neuroimmune diseases. Neuropharmacology 2014.

404. Porters N, de Rooster H, Bosmans T, Baert K, Cherlet M, Croubels S, De Backer P, Polis I: Pharmacokinetics of oral transmucosal and intramuscular dexmedetomidine combined with buprenorphine in cats. J Vet Pharmacol Ther 2014.

405. Brown DC, Boston RC, Coyne JC, Farrar JT: Ability of the canine brief pain inventory to detect response to treatment in dogs with osteoarthritis. J Am Vet Med Assoc 2008, 233: I278-83.

406. Rialland P, Authier S, Guillot M, Del Castillo JR, Veilleux-Lemieux D, Frank $D$, Gauvin $D$, Troncy $E$ : Validation of orthopedic postoperative pain assessment methods for dogs: a prospective, blinded, randomized, placebo-controlled study. PLoS One 2012, 7:e49480.

407. Malek S, Sample SJ, Schwartz Z, Nemke B, Jacobson PB, Cozzi EM, Schaefer SL, Bleedorn JA, Holzman G, Muir P: Effect of analgesic therapy on clinical outcome measures in a randomized controlled trial using client-owned dogs with hip osteoarthritis. BMC Vet Res 2012, 8

408. Hayashida K: Substance $\mathbf{P}$ saporin for bone cancer pain in dogs: Can man's best friend solve the lost in translation problem in analgesic development? Anesthesiology 2013, I I 9:999-1000.

409. Dirig DM, Salami A, Rathbun ML, Ozaki GT, Yaksh TL: Characterization of variables defining hindpaw withdrawal latency evoked by radiant thermal stimuli. J Neurosci Methods 1997, 76:|83-9|.

410. Randall LO, Selitto JJ: A method for measurement of analgesic activity on inflamed tissue. Arch Int Pharmacodyn Ther 1957, I I I:409-19.

4II. Wu WP, Hao JX, Halldner-Henriksson L, Xu XJ, Jacobson MA, Wiesenfeld-Hallin Z, Fredholm BB: Decreased inflammatory pain due to reduced carrageenan-induced inflammation in mice lacking adenosine A3 receptors. Neuroscience 2002, I I 4:523-7.

412. Yaksh TL, Ozaki G, McCumber D, Rathbun M, Svensson C, Malkmus S, Yaksh MC: An automated flinch detecting system for use in the formalin nociceptive bioassay. J Appl Physiol 200I, 90:2386-402

413. Abdelhamid RE, Kovacs KJ, Honda CN, Nunez MG, Larson AA: Resiniferatoxin (RTX) causes a uniquely protracted musculoskeletal hyperalgesia in mice by activation of TRPVI receptors. J Pain 2013, 14:1629-4I.

414. Yalcin I, Charlet A, Freund-Mercier MJ, Barrot M, Poisbeau P: Differentiating Thermal Allodynia and Hyperalgesia Using Dynamic Hot and Cold Plate in Rodents. J Pain 2009, 1 0:767-73.

415. Pircio AW, Fedele CT, Bierwagen ME: A new method for the evaluation of analgesic activity using adjuvant-induced arthritis in the rat. Eur J Pharmacol 1975, 3 I:207-I5.

416. Poole R, Blake S, Buschmann M, Goldring S, Laverty S, Lockwood S, Matyas J, McDougall J, Pritzker K, Rudolphi K, van den Berg W, Yaksh T: Recommendations for the use of preclinical models in the study and treatment of osteoarthritis. Osteoarthritis Cartilage 2010, 18:S10-16.

417. Lorenz J, Grassel S: Experimental osteoarthritis models in mice. Methods Mol Biol 2014, I I94:401-19.

418. Zhang $R X$, Ren $K$, Dubner R: Osteoarthritis pain mechanisms: basic studies in animal models. Osteoarthritis Cartilage 2013 , 2 | : |308-| 5.

419. Brennan TJ, Vandermeulen EP, Gebhart GF: Characterization of a rat model of incisional pain. Pain 1996, 64:493-50I.

420. Nozaki-Taguchi N, Yaksh TL: A novel model of primary and secondary hyperalgesia after mild thermal injury in the rat. Neurosci Lett 1998, 254:25-8.

421. Ness TJ, Gebhart GF: Colorectal distension as a noxious visceral stimulus: physiologic and pharmacologic characterization of pseudaffective reflexes in the rat. Brain Res 1988, 450:153-69.

422. Fioramonti J, Gebhart GF: In vivo and transgenic animal models used to study visceral hypersensitivity. Neurogastroent Motil 2007, 19:20-8.

423. Zhao JB, Liao DH, Nissen TD: Animal models of pancreatitis: can it be translated to human pain study? World J Gastroenterol 2013, 19:7222-30.

424. Saitoh C, Yokoyama H, Chancellor MB, de Groat WC, Yoshimura N: Comparison of voiding function and nociceptive behavior in two rat models of cystitis induced by cyclophosphamide or acetone. Neurourol Urodyn 2010, 29:501-5.

425. Bennett GJ, Xie YK: A Peripheral Mononeuropathy in Rat That Produces Disorders of Pain Sensation Like Those Seen in Man. Pain 1988, 33:87-107.

426. Kim SH, Chung JM: An experimental model for peripheral neuropathy produced by segmental spinal nerve ligation in the rat. Pain 1992, 50:355-63.

427. Shields SD, Eckert WA, 3rd, Basbaum Al: Spared nerve injury model of neuropathic pain in the mouse: a behavioral and anatomic analysis. J Pain 2003, 4:465-70.

428. Challa SR: Surgical animal models of neuropathic pain: Pros and Cons. Int J Neurosci 2014.

429. Tesch GH, Allen T]: Rodent models of streptozotocin-induced diabetic nephropathy (Methods in Renal Research). Diabetes 2006, 55:3335-43.

430. Siau C, Xiao W, Bennett G]: Paclitaxel- and vincristine-evoked painful peripheral neuropathies: loss of epidermal innervation and activation of Langerhans cells. Exp Neurol 2006, 20 I:507-I4. FlOOOPrime RECOMMENDED

431. Schwei MJ, Honore P, Rogers SD, Salak-Johnson JL, Finke MP, Ramnaraine ML, Clohisy DR, Mantyh PW: Neurochemical and cellular reorganization of the spinal cord in a murine model of bone cancer pain. J Neurosci 1999, 19:10886-97.

432. Falk S, Ipsen DH, Appel CK, Ugarak A, Durup D, Dickenson AH, Heegaard AM: Randall Selitto pressure algometry for assessment of bone-related pain in rats. Eur J Pain 2014. 